INFORMES

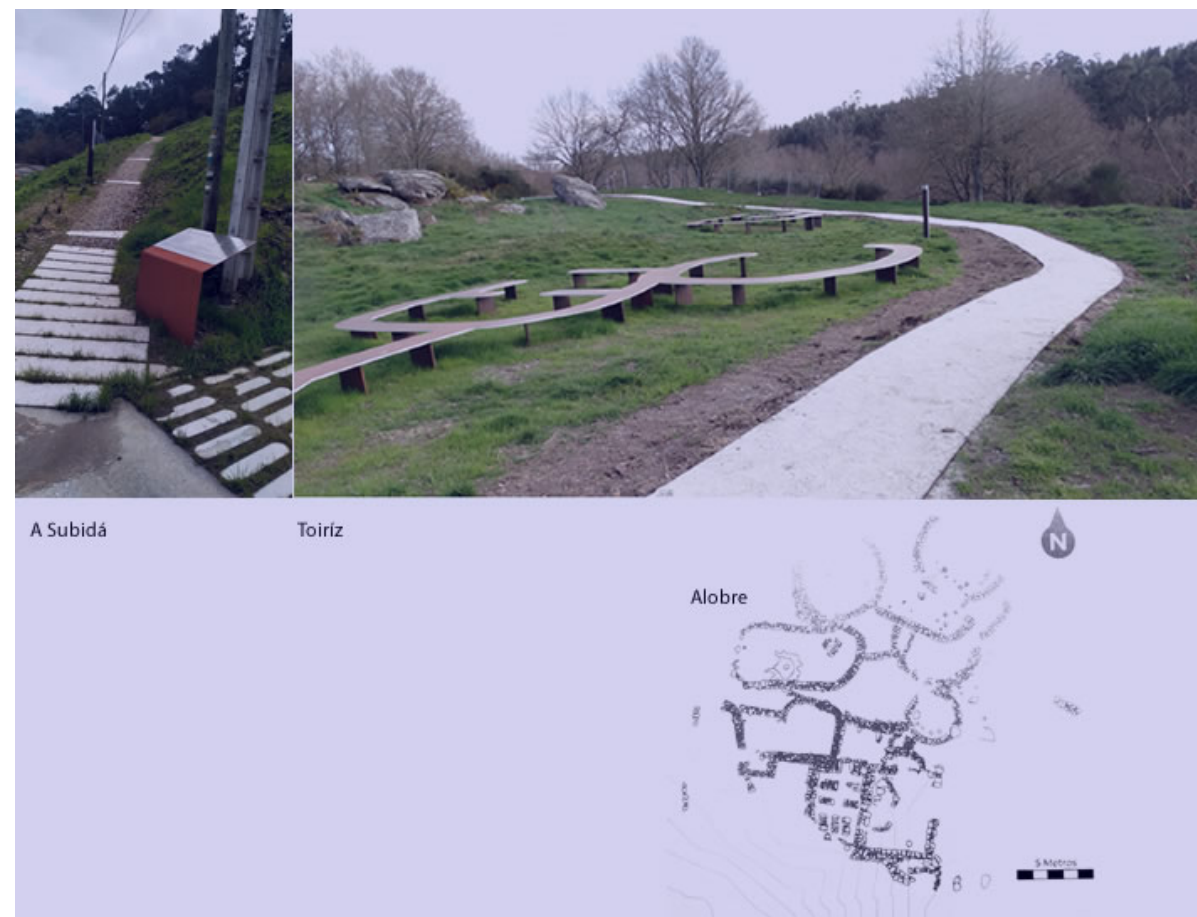

\title{
Informe sobre as intervencións levadas a cabo no proxecto TRAZAS de Pontevedra
}

DOI: 10.17075/isilcptp.2021

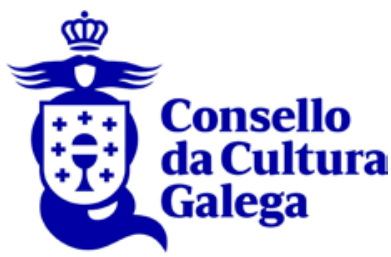




\section{ÍNDICE}

1. Introdución

2. Orixe das actuacións 6

2.1. Ruta turística $\quad 7$

2.2. Estratexia para o desenvolvemento 12

3. Fases das actuacións de valorización $\quad 15$

3.1. Fase de investigación $\quad 16$

$\begin{array}{ll}\text { 3.2. Fase de conservación } & 19\end{array}$

3.3. Fase de presentación e interpretación $\quad 21$

3.4. Fase de xestión 23

$\begin{array}{lr}\text { 4. Avaliación das actuacións proxectadas } & 23\end{array}$

4.1. Análise da documentación $\quad 24$

$\begin{array}{ll}\text { 4.2. Estudo antropolóxico } & 30\end{array}$

4.3. Avaliación da adecuación das actuacións $\quad 31$ Finalidade 31

Rigorosidade histórica $\quad 32$ Interdisciplinariedade $\quad 32$

INFORMES Autenticidade e mínima intervención $\quad 33$

5. Elementos de interpretación 33

5.1. Cartelaría e sinalización $\quad 34$

5.2. Elementos (des)contextualizadores, pseudorreconstrucións

6. Impacto sobre o rexistro arqueolóxico das actuacións 36

7. Conclusións

$\begin{array}{lc}\text { 8. Bibliografía } & 43\end{array}$ 


\section{INTRODUCIÓN}

Representantes das asociacións UMIAVIVO, Colectivo pola defensa do territorio ANOVATERRA, asociación Irmandade ILLA DE TAMBO e Colectivo pola defensa do Patrimonio AFORNEIRIÑA solicitaron o 15 de decembro de 2020 o posicionamento do Consello da Cultura Galega (CCG) en relación coa denuncia pública e ante os organismos con competencias na xestión e defensa do patrimonio cultural verbo das intervencións realizadas sobre tres castros da provincia de Pontevedra: Castro de Toiriz (Silleda), Castro da Subidá (Marín) e Castro de Alobre (Vilagarcía de Arousa) e sobre a intención de desenvolver actuacións semellantes noutros 15 castros da provincia.

As actuacións ás que se refire a solicitude foron executadas polo Ministerio de Fomento dentro do programa de Rehabilitación Arquitectónica como resultado dun Protocolo asinado entre o Ministerio e a Deputación de Pontevedra no ano 2015 para desenvolver actuacións sobre os xacementos galaico-romanos da provincia de Pontevedra incluídos nun "Programa provincial integral para o aproveitamento turístico dos xacementos galaico-romanos”.

O Consello da Cultura Galega ten entre as súas competencias analizar cantas cuestións se refiran ao patrimonio cultural e elevar aos poderes públicos da Comunidade Autónoma informes e propostas a favor da defensa e promoción dos valores culturais do pobo galego. Na solicitude cuestiónase o modelo de intervención e de posta en valor do patrimonio arqueolóxico que se está aplicando nas intervencións realizadas e as que se pretende realizar cos mesmos criterios, xa que afectan un número importante de castros e mobilizan unha contía elevada de fondos públicos. Dende o exercicio do dereito ao patrimonio trasládase o rexeitamento social a estas intervencións polo seu impacto para a identidade e valores dos xacementos, avalado tamén por expertos do ámbito da arqueoloxía.

O 15 de xaneiro de 2021 solicitouse información sobre esta actuación á Dirección Xeral do Patrimonio Cultural (DXPC) da Consellería de Cultura, Educación e Universidade, que remitiu o 10 de febreiro, e á Deputación de Pontevedra, que achegou a información solicitada o 8 de febreiro.

Como metodoloxía de traballo para a elaboración do presente informe procedeuse, en primeiro lugar, á análise de toda a documentación dispoñible: 
o Nos enlaces facilitados na solicitude de informe da plataforma de contratación do Ministerio de Transportes, Mobilidade e Axenda Urbana (antes Fomento):

Plataforma de Contratación del Sector Público (contrataciondelestado.es) relativa ao Concurso de proyectos con intervención de jurado para las obras de restauración y musealización de los yacimientos galaico-romanos de la provincia de Pontevedra:

- Pregos de prescricións técnicas e de cláusulas administrativas do Concurso (PPT)

- Composición do comité de expertos

- Acta no 2 do xurado que contén o ditame do concurso

- Proposta seleccionada no concurso co lema IN NATURA VERITAS

OBRAS DE RESTAURACIÓN Y MUSEALIZACIÓN DE LOS YACIMIENTOS GALAICO-ROMANOS DE PONTEVEDRA. TRAZAS DE PONTEVEDRA, FASE 1. Expte_201900000095 | Ministerio de Transportes, Movilidad y Agenda Urbana (mitma.gob.es), que comprende:

- Memoria

- Planimetría

o Alobre Vilagarcía de Arousa

o Castro a Subida Marín

o Toiriz Silleda

o Detalles

- Memoria de musealización

- Medicións e orzamento

- Prego de prescricións técnicas particulares

- Identidade visual

- Reportaxe fotográfica

o A documentación facilitada pola Deputación Provincial, que engade á do proxecto o Informe relativo aos proxectos de musealización do Castro de Alobre (Vilagarcía de Arousa), Castro de Toiriz (Silleda) e Castro da Subidá (Marín), elaborado polo arqueólogo provincial e datado o 15 de febreiro de 2019; e o 
Protocolo asinado no ano 2015 e a autorización remitida pola DXPC do proxecto "Trazas de Pontevedra, fase I" correspondente á musealización dos castros de Alobre (Vilagarcía de Arousa), A Subidá (Marín) e Toiriz (Silleda)”.

o Consultáronse, ademais, o planeamento urbanístico dos concellos de Silleda, Marín e Vilagarcía de Arousa, o Plan Básico Autonómico, as fotografías históricas dispoñibles na Fototeca Dixital do Instituto Xeográfico Nacional e a bibliografía que se relaciona no último apartado do informe.

A LEI 5/2016, do 4 de maio, do patrimonio cultural de Galicia (LPC/16) establece, no artigo 44. Criterios de intervención nos bens, uns criterios xerais e comúns a todos os tipos de bens catalogados ou declarados BIC. Aínda que contempla de maneira xenérica a metodoloxía e criterios que se deben seguir nas actuacións sobre o patrimonio arquitectónico ademais de contemplar que se establecerán mediante instrucións todos os aspectos relativos a estes proxectos, especialistas, criterios, técnicas etc.- (art. 89) e incluso, dunha maneira moi xenérica, os Criterios para a intervención no patrimonio industrial (art. 105), non desenvolve os mesmos aspectos en relación co patrimonio arqueolóxico, limitándose a sinalar que "A consellaría competente en materia de patrimonio cultural velará por que as obras e actuacións necesarias para a apertura dun xacemento á visita pública non atenten contra o carácter arqueolóxico, contra o seu valor cultural e científico, contra a súa relación co contorno e co seu contexto territorial e contra a valoración cultural da paisaxe”.

Unha vez revisada a documentación, decidiuse levar a cabo un informe en que analizar os conceptos e deseño da iniciativa de posta en valor destes xacementos da provincia de Pontevedra establecidos no proxecto e realizar a análise das actuacións previstas, enmarcándoa nunha estrutura dos aspectos que deben atender e resolver as actuacións de valorización e musealización de xacementos arqueolóxicos no territorio e dos principios e os criterios aos que debería responder este tipo de intervencións, con especial incidencia nos aspectos sinalados na LPC/16 respecto ao carácter arqueolóxico, ao valor cultural e científico, á relación co contorno e co contexto territorial e á valoración cultural da paisaxe. A partir desta análise é como consideramos que dende o Consello da Cultura Galega se podería emitir un parecer argumentado sobre as intervencións e proxectos que se están a desenvolver nestes xacementos arqueolóxicos tendo como obxectivo a súa posta en valor. 


\section{ORIXE DAS ACTUACIÓNS}

A Deputación Provincial de Pontevedra vén desenvolvendo na última década unha intensa actividade no ámbito da arqueoloxía, na que destaca a creación do Centro Provincial de Xestión do Coñecemento Arqueolóxico ${ }^{1}$, centro dependente de Turismo Rías Baixas do servizo de turismo da Deputación de Pontevedra, que ten como finalidade contribuír a afondar e mellorar o coñecemento arqueolóxico dos restos atopados en Galicia en xacementos galaico-romanos, co fin de coñecer mellor a nosa historia e cultura, poñela en valor e contribuír á súa difusión entre a sociedade.

Estas non son as primeiras intervencións arqueolóxicas que promove a Deputación de Pontevedra, que xa realizou con anterioridade intervencións no Monte do Castro en Ribadumia, na Lanzada ${ }^{2}$ ou no Castro Alobre en Vilagarcía de Arousa.

Estes xacementos, xunto con Castrolandín ${ }^{3}$, que foi escavado recentemente ${ }^{4}$, e outros catorce da provincia de Pontevedra están incluídos nun programa de Posta en valor dos xacementos galaicoromanos da provincia de Pontevedra ${ }^{5}$ que promove a Deputación de Pontevedra coa colaboración do Ministerio de Fomento. Este programa ten como obxectivo "mellorar a comprensión da dinámica socioeconómica de Galicia na antigüidade, ofrecer unha explicación da articulación territorial que permanece desde a Idade de Ferro ata a tardorromana e tamén contribuír á ampliación da oferta turística, tanto á desestacionalización coma á captación de novos turistas potenciais,

\footnotetext{
${ }^{1}$ https://www.depo.gal/documents/1076146/7651074/CXCA_Carta_de_servizos.pdf/9293cc51454d-497f-8b7d-ec26bdd41e39.

${ }^{2}$ Estas escavacións realizáronse con cargo ao programa Pousadas do Salnés, cofinanciado polo Fondo Europeo de Desenvolvemento Rexional (Feder) e a propia Deputación como "Escavacións accesibles englobadas no ámbito de aplicación do programa Protección e preservación do patrimonio cultural, con actuacións de recuperación de espazos históricos nas escavacións arqueolóxicas da Lanzada, en Sanxenxo, e do monte do Castro en Ribadumia. Coa posta en valor destes xacementos rexenerarase un espazo libre nos seus respectivos termos municipais e coa súa adecuación ás visitas xerarase un novo recurso do turismo cultural que funcione como un factor de atracción para a comarca do Salnés” https://codigocero.com/A-Deputacion-dePontevedra-pon-en.

${ }^{3}$ Un recente convenio de Deputación e CSIC para poñer en valor o centro castrexo do pazo de Liñares incluirá prospeccións nos castros de Bendoiro (Lalín), Montaz (Silleda) e Castrolandín (Cuntis), explica Carmela Silva, La Voz de Galicia 18/10/2020,

https://www.boe.es/diario_boe/txt.php?id=BOE-A-2020-14534.

${ }^{4}$ Unha intervención dirixida por César Parcero Oubiña dentro do proxecto ArqDePo do Incipit (CSIC), http://www.incipit.csic.es/es/proyecto/arqdepo.

${ }^{5}$ https:// www.depo.gal/-/plans-e-proxectos-turismo-castrodezaposta-en-valor-dosxacementos-galaico-romanos-da-provincia-de-pontevedra
} 
especialmente en mercados estranxeiros, a través dunha oferta cultural innovadora” 6 .

\subsection{Ruta turística}

Na súa orixe, como xa se sinalou, as actuacións sobre os xacementos galaico-romanos da provincia de Pontevedra formaban parte dun "Programa provincial integral para o aproveitamento turístico dos xacementos galaico-romanos” con distintos obxectivos agrupados no ámbito científico, no ámbito turístico e no ámbito socioeconómico. Entre os primeiros incluíanse os de comprensión da dinámica socioeconómica da provincia e de Galicia na antigüidade e a explicación da articulación territorial dende a Idade de Ferro á Idade Media, ademais dos de formación e cooperación con entidades universitarias. Os segundos pretendían revalorizar o turismo de calidade, ampliar ao turismo cultural a oferta turística da provincia, desestacionalizala e captar novos turistas. Finalmente, os obxectivos socioeconómicos ligábanse á creación de emprego, implicación de institucións públicas e privadas, recuperación económica e freo ao despoboamento dos concellos do interior e á recuperación dos espazos patrimoniais como espazos sociais (Protocolo 20157).

Nas bases do concurso de ideas convocado polo Ministerio de Fomento para seleccionar os futuros redactores dos proxectos de intervención nos xacementos, inclúese o deseño da imaxe e marca da ruta dos xacementos galaico-romanos da provincia de Pontevedra, incluíndo na actuación, ademais da musealización individualizada dos xacementos, a definición e implementación dunha imaxe conxunta da ruta. Un dos obxectivos principais da posta en valor da ruta sería o de expresar un discurso e unha musealización coherente co seu concepto, o xa sinalado da interpretación sobre o territorio e o seu pasado, e desenvolver un eixe temático potente que poña en valor os períodos máis singulares do pasado da provincia (PPT).

Resulta manifesta a contradición entre os obxectivos científicos da ruta, que se basean na comprensión da dinámica socioeconómica da provincia e de Galicia na antigüidade e na explicación da articulación territorial dende a Idade de Ferro á Idade Media, e o feito de empregar como ámbito territorial, no que se deseña e ao que se referencia a ruta para comprender estes aspectos, o da provincia decimonónica, un espazo

\footnotetext{
${ }^{6}$ https://www.depo.gal/web/edepo/xacementos

${ }^{7}$ Protocolo asinado no ano 2015 entre a Deputación de Pontevedra o Ministerio de Fomento para desenvolver estas actuacións.
} 

históricas.

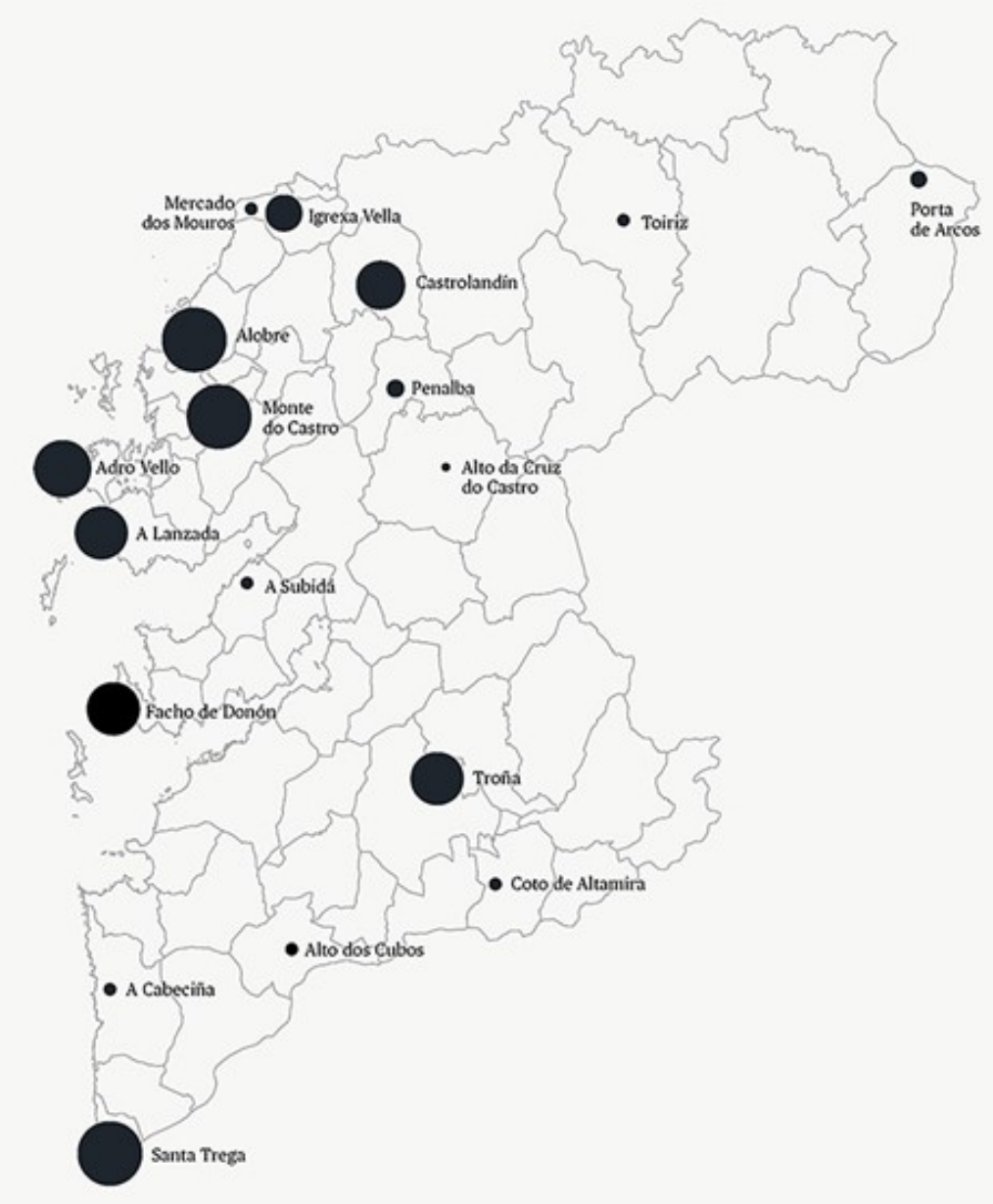

Fig. 1. Mapa da provincia de Pontevedra coa localización dos xacementos obxecto do proxecto, o tamaño dos puntos reflicte o diferente nivel de intervención que se pretende realizar na proposta presentada por LEVE (Leve Projects, Kultura, idees i estratègies per al patrimoni, S.L., Goñi Studio), en http://www.levenet.com/es/projecte/terra-de-castros/\#gallery-2 


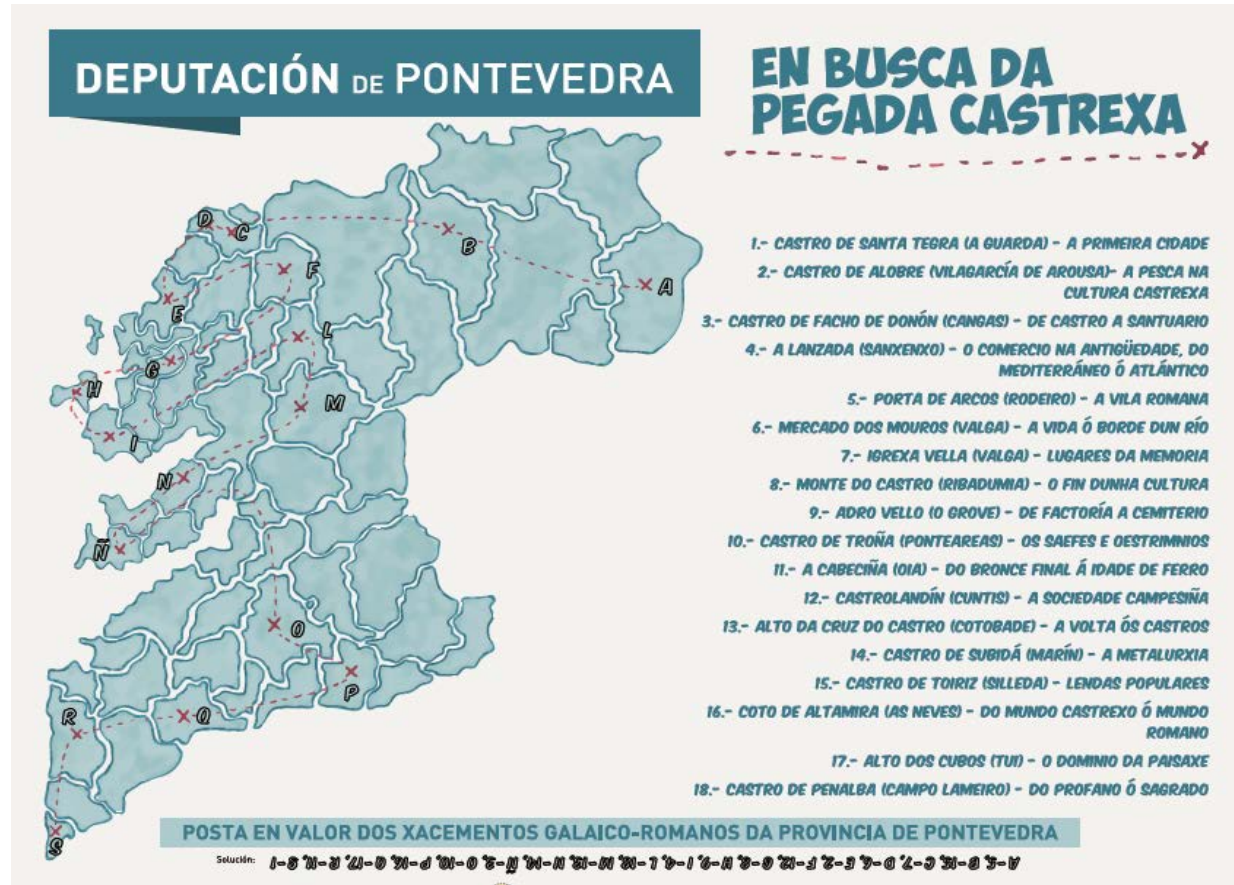

Fig. 2. Plano da ruta dos xacementos galaico-romanos da provincia de Pontevedra creado como recortable para escolares. 4106-98a5-1320d414

A ruta consiste na suma dun conxunto de 18 xacementos que se pretenden difundir propiciando a visita "contextualizada no marco da ruta” e resaltando un "carácter único relacionado co carácter científico do sitio arqueolóxico" que reflicte o plano creado como recortable para escolares (Fig. 2) que recolle os 18 xacementos e a identificación dese “carácter único”. Estes xacementos son os seguintes:

1. Castro de Santa Tegra (A Guarda)

https://www.depo.gal/informacionxacementos?p_p_auth=MC9zUPm7\&p_p_id=56_INSTANCE_xQ1Z cjokkqe4\&p_p_lifecycle $=0 \& p \_p \_c o l \_i d=\_118 \_I N S T A N C E \_c A D f k R 0$ u1FoR column-

0\&p_p_col_count $=1 \& \_56 \_I N S T A N C E \_x Q 1 Z c j o k k q e 4 \_$groupId=107 6146\&_56_INSTANCE_xQ1Zcjokkqe4_articleId=1668323

2. Castro de Troña (Ponteareas)

https://www.depo.gal/informacionxacementos?p_p_auth=YTh9hDr5\&p_p_id=56_INSTANCE_xQ1Zci okkqe4\&p_p_lifecycle $=0 \& p \_p \_c o l \_i d=\_118 \_I N S T A N C E \_c A D f k R 0 u$ $\underline{1 \text { FoR_column- }}$ 
$\underline{0 \& p \_p \_ \text {col count }=1 \& \text { 56 INSTANCE } x Q 1 Z c j o k k q e 4 \text { groupId }=107}$ 6146\& 56 INSTANCE xQ1Zcjokkqe4 articleId=1668371

3. Castro do Monte do Facho (Cangas) https://www.depo.gal/-/yacimiento-castro-do-facho-de-donon

4. A Lanzada (Sanxenxo) https://www.depo.gal/-/xacemento-a-lanzada

5. Adro Vello ( O Grove) https://www.depo.gal/-/xacemento-adro-vello

6. O Castro (Ribadumia) https://www.depo.gal/informacionxacementos?p_p_auth=SxCr15Pp\&p_p_id=56_INSTANCE_xQ1Zcjo kkqe4\&p_p_lifecycle $=0 \& p \_p \_c o l \_i d=118 \_$INSTANCE_cADfkR0u1 FoR column-

0\&p_p_col_count $=1 \& \_56 \_I N S T A N C E \_x Q 1 Z c j o k k q e 4$ groupId $=107$ 6146\&_56_INSTANCE_xQ1Zcjokkqe4_articleId=1668420

7. Porta de Arcos (Rodeiro) https://www.depo.gal/-/yacimiento-porta-de-arcos

8. Castrolandín (Cuntis) https://www.depo.gal/-/yacimiento-castrolandin

9. A Cabeciña (Oia) https://www.depo.gal/-/xacemto-a-cabecina 10. A Subidá (Marín) https://www.depo.gal/-/yacimiento-castro-da-subida

11. Castro Alobre (Vilagarcía de Arousa) https://www.depo.gal/-/yacimiento-castro-alobre

12. Castro do alto dos Cubos (Tui), Idade do Ferro e época romana I a.C.-III d.C. https://www.depo.gal/-/yacimiento-alto-dos-cubos

13. Alto da Cruz do Castro (Cotobade) https://www.depo.gal/-/xacemento-alto-da-cruz-do-castro 
14. Coto de Altamira (As Neves)

https://www.depo.gal/informacionxacementos?p_p_auth=0tQwWIEy\&p_p_id=56_INSTANCE_xQ1Zc jokkqe $4 \& p \_p \_$lifecycle $=0 \& p \_p \_c o l \_i d=118$ INSTANCE_cADfkR0u 1FoR column-

0\&p_p_col_count=1\&_56_INSTANCE_xQ1Zcjokkqe4_groupId=107 6146\&_56_INSTANCE_xQ1Zcjokkqe4_articleId=1668349

15. Igrexa Vella (Valga)

https://www.depo.gal/-/xacemento-igrexa-vella

16. Castro de Penalba (Campo Lameiro)

https://www.depo.gal/informacionxacementos?p_p_auth=MC9zUPm7\&p_p_id=56_INSTANCE_xQ1Z cjokkqe4\&p_p_lifecycle $=0 \& p \_p \_c o l \_i d=\_118 \_$INSTANCE_cADfkR0 u1FoR column-

0\&p_p_col_count=1\&_56_INSTANCE_xQ1Zcjokkqe4_groupId=107 6146\&_56_INSTANCE_xQ1Zcjokkqe4_articleId=4023803

17. Mercado dos Mouros (Valga)

https://www.depo.gal/-/xacemento-mercado-dos-mouros

18. Castro de Toiriz (Silleda)

\section{https://www.depo.gal/-/yacimientos-castro-de-toiriz}

A escolla dos xacementos dentro da totalidade de xacementos da Idade do Ferro documentados na provincia non está xustificada na documentación da que dispoñemos, porén parece responder máis a un criterio de distribución xeográfica (na que estean representados castros de toda a provincia) ca a un criterio científico, mesturando xacementos con estruturas visibles, escavados, con outros nos que non son visibles e non hai unha intervención que permitira caracterizalos en profundidade como para poder seleccionar os criterios para a súa posta en valor. Cómpre considerar que o patrimonio arqueolóxico é, en xeral, un patrimonio fráxil e de difícil lexibilidade, aspecto ao que hai que engadir a heteroxeneidade dos xacementos seleccionados para a súa musealización, no que respecta á súa cronoloxía, escala, estratificación temporal, situación dos restos, que estean escavados ou soterrados etc., polo que sería conveniente unha reflexión previa e debidamente razoada, así como individualizada, sobre a conveniencia e viabilidade de abrilos ao público e en que medida as necesidades de intervención que require esa musealización poden ser ou non compatibles coa súa 
protección e conservación como condición previa á súa inclusión na ruta. A selección do "carácter único”, resaltando algún dos aspectos que caracterizan o xacemento, que, en realidade, non sempre é único, pois moitas veces presentan características compartidas con outros xacementos, e tampouco é sempre cientificamente o máis relevante, pode supoñer que esa unicidade se converta no leitmotiv de cada xacemento, o que pode levar á simplificación, á redución do valor cultural e a unha certa banalización dalgún dos xacementos. De aí a importancia dunha correcta, individualizada e científica caracterización previa antes de seleccionar os xacementos máis axeitados para a súa escolla como elementos representativos da Idade do Ferro na provincia de Pontevedra de cara á súa posta en valor (asumindo que esta delimitación é presentista).

Outra cuestión que considerar dende a perspectiva da conservación destes xacementos como bens patrimoniais é a do carácter que adquiren unha vez musealizados e, en consecuencia, identificar de que institución dependerán para os efectos da súa xestión como bens museográficos, aspecto que tampouco ten resposta na documentación analizada.

\subsection{Estratexia para o desenvolvemento}

As intervencións desenvólvense dentro do programa de Rehabilitación Arquitectónica do Ministerio de Fomento ${ }^{8}$ seguindo o Protocolo asinado entre este e a Deputación de Pontevedra no ano 2015. Este programa está dirixido á conservación e enriquecemento do patrimonio arquitectónico español e con el fináncianse actuacións de rehabilitación, restauración e recuperación de edificios con valor patrimonial, convocando concursos de proxectos e obras e acometendo obras de rehabilitación en edificios históricos, actuando Fomento como órgano de contratación. De partida, os elementos arqueolóxicos que neste caso se inclúen neste programa son de natureza moi distinta, na súa formación e conservación, a un edificio.

O Programa provincial integral para o aproveitamento turístico dos xacementos galaico-romanos de Pontevedra encáixase neste programa e, probablemente por ese encaixe, sepáranse as actuacións arqueolóxicas e de escavación das actuacións de accesibilidade e musealización, quedando as primeiras a cargo da Deputación de Pontevedra e asumindo Fomento as segundas. Este é un segundo

${ }^{8}$ https://www.mitma.gob.es/arquitectura-vivienda-y-suelo/arquitectura-yedificacion/rehabilitacion-arquitectonica 
problema de partida, porque os xacementos deben concibirse e intervirse como unha unidade que, neste caso, ten especificidades propias.

Os xacementos incluídos no programa están pendentes no momento da convocatoria do concurso de actuacións previas: seis deles de escavación e cinco deles de actuacións de consolidación, restauración e outras actuacións previas (Prego de prescricións técnicas do concurso, PPT). Os sete xacementos unicamente pendentes de musealización, sinalización e accesos inclúen os castros de Toiriz e A Subidá, nos que xa se realizaron as obras, mentres que o terceiro dos xa intervidos, o castro de Alobre, está incluído no PPT entre os castros pendentes de escavación.

Para a contratación dos proxectos de musealización convocouse un concurso de ideas que tiña como obxectivo seleccionar un anteproxecto que servise de modelo e que se desenvolveu sobre un dos xacementos, o Monte do Castro en Ribadumia, castro que se recolle no PPT como un dos pendentes de consolidación, restauración e outras actuacións previas, a pesar do cal se considera viable deseñar a musealización do xacemento sen antes acometelas. A documentación en base á que se desenvolve este anteproxecto é unha ficha que contén unha sucinta descrición física e un plano das escavacións realizadas. Este sería outro problema de partida, planificar unha musealización sen ter feitas as actuacións necesarias para que o ben estea nas condicións necesarias para tal fin.

A composición do equipo que requiriu o concurso, dirixido por un arquitecto con experiencia en musealización e posta en valor de bens culturais (non necesariamente arqueolóxicos), comprende un responsable de contidos e un deseñador creativo, todos eles con experiencia no seu ámbito en museos e exposicións. Non se requiriu a intervención no equipo de ningún profesional que tivese formación e cualificación suficiente en materia de investigación, conservación e restauración de bens arqueolóxicos, polo que non se conta con investigación aplicada aos proxectos que contribúa a establecer criterios de intervención, a pesar de que esta debe confluír coa investigación e coñecemento científico do ben. Esa composición do equipo pode contravir o establecido no artigo 43.3 da LPC/16, que require que os proxectos de intervención sexan redactados por un equipo interdisciplinario integrado por profesionais con competencias que se adecúen ás intervencións que se proxecten. 
Os criterios e baremación para a selección do traballo inclúen en dous dos seus apartados referencias á conservación e restauración, puntuando a complementariedade destas coa musealización e o respecto aos criterios de restauración. Resulta sorprendente a inclusión destes aspectos nos criterios de selección cando a conservación e a restauración dos xacementos non son obxecto dos proxectos que se van contratar, xa que as actuacións que asume o Ministerio de Fomento, e que polo tanto se incluirán nos proxectos, son as de accesibilidade e musealización, e non só isto, senón que os proxectos se iniciarán nos castros en que xa estean finalizadas as actuacións de escavación e consolidación e iranse desenvolvendo a medida que a Deputación, que asume esas actuacións, as execute.

A proposta seleccionada "pretende achegar os visitantes á natureza e expoñer os seus sentidos a un asentamento romano imaxinado en funcionamento". Trátase dun "proxecto que integra paisaxismo, renovación e musealización. Achegámonos a el respectando o medio natural e arqueolóxico que o rodea, para darlle unha identidade propia, sostible, sinxela e, ao mesmo tempo, que supoña unha experiencia única para o visitante" ${ }^{9}$. O xurado resalta que se trata dunha "propuesta respetuosa con las edificaciones existentes y que a través de una visión integral del contexto aporta calidad escénica y amabilidad a la visita a los castros”.

Define a proposta unhas "estratexias de acción territorial que poden ser exportadas a calquera dos 18 castros”. Establece seis tipos de escenas ou lugares comúns ao carácter paisaxístico das localizacións: Bosque pechado/claros, Pradeira, Matogueira/monte baixo, Castros, Noiro de rocha/canteira, Noiro vexetal, e fixa para cada unha delas as liñas básicas de actuación en termos de vexetación, solados, iluminación e intervencións sonoras ${ }^{10}$. Cuarto dos problemas de partida, non atender ao contexto do xacemento, que é unha das principais singularidades do rexistro arqueolóxico e da paisaxe en que se insire.

A proposta seleccionada está deseñada como unha actuación paisaxística na que se trata o espazo do xacemento e os seus accesos para modificar as súas características visibles, vexetación, estruturas de

\footnotetext{
${ }^{9}$ Tradución de "The AGi proposal aims to bring visitors close to nature and to expose their senses to an imagined Roman settlement in operation.We have approached it with all due respect to the natural and archaeological environment that surrounds it, in order to provide it with an own, sustainable, simple identity and, at the same time, that represents a unique experience to the visitor", https://www.archdaily.com/804116/agi-wins-competition-to-transform-galicianroman-ruins-into-sensual-museum.

${ }^{10}$ https://www.agi-architects.com/work/in-natura-veritas-2-2/
} 
pavimentacións, iluminación... (como se fose un edificio). Mais non se atende aos valores dos xacementos, nin aos arqueolóxicos, nin aos paisaxísticos (como fitos no territorio), nin aos valores sociais, nin aos documentais. $\mathrm{O}$ “castro” é un elemento máis do ámbito en que se desenvolve a intervención paisaxística. Non é o elemento en que se focaliza a intervención e non se ten en conta a súa singularidade.

Algunhas das eivas sinaladas neste proceso pódense atribuír ao feito de encaixar unha actuación de musealización ou interpretación de xacementos arqueolóxicos nuns instrumentos, pregos e concurso deseñados para actuacións de restauración arquitectónica, coas que non gardan relación. Poñer en valor un xacemento arqueolóxico ten unhas especificidades que difiren moito da posta en valor dun edificio. De aí a importancia de contar no proxecto con especialistas en musealización de xacementos arqueolóxicos.

\section{FASES DAS ACTUACIÓNS DE VALORIZACIÓN}

As actuacións proxectadas e executadas sobre os tres xacementos arqueolóxicos de Toiriz, A Subidá e Alobre, dentro das intervencións definidas no art. 40 da LPC/16, só poderían encadrarse nas de Valorización, definidas como "medidas e accións sobre os bens culturais ou o seu ámbito próximo que teñan por obxecto permitir a súa apreciación, facilitar a súa interpretación e acrecentar a súa difusión, especialmente no ámbito educativo, e a súa función social”. A LPC/16 non contempla expresamente estas actuacións de valorización como intervención arqueolóxica, aínda que algunhas das que comprende o concepto de ‘valorización’ poden estar incluídas nos “labores de protección, acondicionamento, conservación, consolidación e restauración arqueolóxica, entendidos como as intervencións en xacementos arqueolóxicos encamiñadas a favorecer a súa conservación e preservación e que, en consecuencia, permitan o seu desfrute e acceso público e faciliten a súa comprensión e uso social” que recolle o art. 95 f) da LPC/16.

Nin a LPC/16 nin a Lei 7/2021, do 17 de febreiro, de museos e outros centros museísticos de Galicia (LMG/21) contemplan a natureza museística de espazos ou conxuntos culturais como si fan outras normas como a Lei 8/2007, do 5 de outubro, de museos e coleccións museográficas de Andalucía, nin definen, polo tanto, actuacións de musealización como son denominadas as obras sobre estes xacementos arqueolóxicos. Malia que os proxectos se denominen de restauración e 
musealización, non inclúen ningunha actuación de restauración ${ }^{11}$ arqueolóxica e, no caso de que así fose, esas actuacións terían a consideración de intervención arqueolóxica e estarían sometidas ás condicións que establecen a LPC/16 e o Decreto que regula esa actividade.

Entendemos o concepto de musealización, no sentido que propón Villalobos-Gómez na súa tese de doutoramento, Arqueología, proyecto y paisaje: musealización in situ de los dólmenes de Antequera do ano 2015, como "a musealización dun xacemento non é senón unha forma concreta de valorización e explicación in situ dos seus valores culturais”:

Musealizar in situ un yacimiento arqueológico significa dotarlo de los significados culturales asociados a un museo en la medida en que lo hacemos accesible al público y convertimos sus contenidos en objeto de visita como si se tratara de un museo al abierto o una exposición in situ sobre sí mismos. Esto implica conocerlo, documentarlo, delimitar su entorno, estudiar la figura de protección más adecuada, asegurar su conservación, compatibilizar los posibles usos públicos, organizar los recorridos, acondicionarlo paisajísticamente y fundamentalmente saber explicarlo. Se prefiere hablar de musealización por las referencias a la institución museística y la connotación a otros aspectos de la tutela; y, en todo caso, de presentación al público del yacimiento o explicitación de sus valores culturales. La musealización del yacimiento no es sino una forma concreta de valorización o explicitación in situ de sus valores culturales.

Fig. 3. Extracto da tese de Villalobos-Gómez (2015), na que se expón o concepto de musealización in situ de xacementos arqueolóxicos que consideramos que se debería seguir no caso que nos ocupa, así como en calquera outro que teña como obxectivo a posta en valor dun xacemento deste tipo.

\subsection{Fase de investigación}

A base da musealización dos xacementos arqueolóxicos debe ser a investigación, xa que a esta lle corresponde a presentación das evidencias materiais atopadas nos traballos de investigación realizados previamente. Porén a primeira actuación que cómpre desenvolver debe

\footnotetext{
${ }^{11}$ Accións para restituír o ben ou as súas partes ao seu debido estado, sempre que se dispoña da documentación suficiente para coñecelo ou interpretalo, con respecto aos seus valores culturais. Art. 40 LPC/16.
} 
ser a de investigación para estudar e documentar o xacemento antes da súa posta en valor, polo que non se debe realizar esta sen un coñecemento suficiente do ben arqueolóxico.

Como xa se sinalou, no desenvolvemento das actuacións de Posta en valor dos xacementos galaico-romanos da provincia de Pontevedra considéranse os castros de Toiriz e A Subidá pendentes de musealización, sinalización e accesos, mentres que o castro de Alobre inclúese entre os pendentes de escavación.

No castro de Toiriz a intervención de musealización apóiase nos resultados da prospección xeofísica e xeomagnética realizada no ano 2012, resultados cualificados como non concluíntes polo arqueólogo da Deputación ${ }^{12}$; con todo, a partir deles elaborouse o esbozo de estruturas e un modelo 3D ao que se referencian as pezas de aceiro que "ilustran" o xacemento imitando a planta das edificacións castrexas.

Na proposta relativa ao castro da Subidá relaciónanse as intervencións realizadas ata o ano 2011. Na Memoria do proxecto non se mencionan as actuacións levadas a cabo nos anos 2017-2018, que consistiron na escavación fundamentalmente do celeiro escavado e na consolidación deste e dos muros do sistema de drenaxe, así como no rexistro dunha canteira tradicional que tería alterado o xacemento nesa zona $^{13}$; emporiso, na Memoria de musealización faise referencia a estas actuacións, se ben non parece recoller o coñecemento do xacemento derivado desa intervención. Nela non se menciona o celeiro nin o "sofisticado" sistema de drenaxe escavados e consolidados ${ }^{14}$. Considérase na Memoria que a porcentaxe escavada do xacemento que se musealiza é do $1 \%$.

A falta de comprensión deste xacemento no seu contexto territorial e na paisaxe cultural en que se integra evidénciana descricións como a seguinte: "Se encuentra rodeado en su base por edificaciones y carreteras del extrarradio de Marín. En época reciente, la ampliación del núcleo urbano en su zona más oriental afectó directamente al castro”, lonxe da comprensión do poboamento e da súa relación co mundo castrexo.

\footnotetext{
${ }^{12}$ Informe de febreiro de 2019 do arqueólogo provincial Rafael María Rodríguez Martínez.

${ }^{13} \mathrm{http}$ ///www.concellodemarin.es/campana-de-escavacion-e-consolidacion-no-castro-dasubida/

${ }^{14}$ https://www.diariodepontevedra.es/gl/articulo/noticias/un-granero-el-nuevo-hallazgo-deun-castro-da-subida-todavia-por-explorar/20170622000000330797.html
} 
O castro de Alobre, como xa sinalamos, está incluído no PPT (2015) entre os xacementos pendentes de escavación e nel íanse realizar tamén actuacións de consolidación e restauración, ademais da recreación de elementos singulares para unha adecuada explicación do xacemento. Ningunha destas actuacións foron incluídas no proxecto de musealización, senón que, como constaba no Protocolo asinado co Ministerio de Fomento, foron realizadas pola Deputación Provincial de Pontevedra ${ }^{15}$.

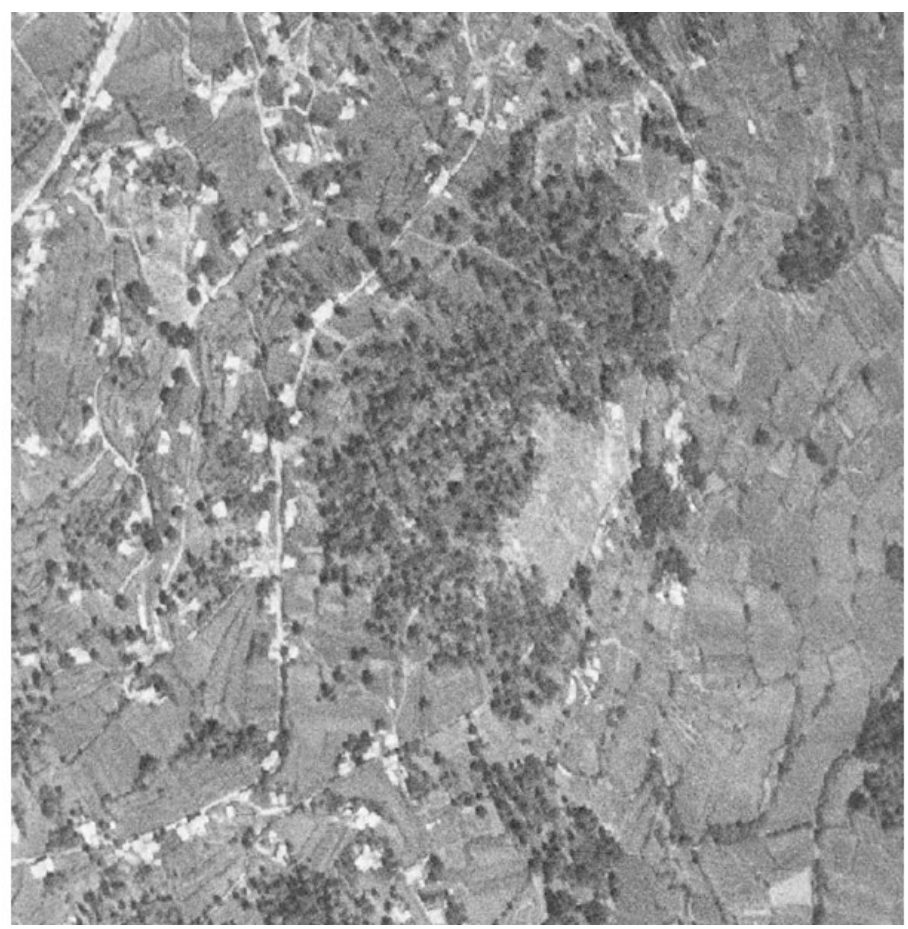

Fig. 4. O Castro da Subidá e os asentamentos situados ao pé do Castro, Sete Espadas ao oeste e Cidrás ao leste. Extracto da fotografía do voo americano de 1956-1957.

O proxecto do Castro Alobre parte do estado do xacemento despois de realizadas esas intervencións en que se consolidaron as estruturas, se reconstruíron dous muros, se recrearon dúas chemineas e parte do pavimento do hipocausto; empregouse area de distintas cores

\footnotetext{
${ }^{15}$ «Carmela Silva lembrou que en Castro Alobre, que forma parte do protocolo asinado entre a Deputación de Pontevedra e o Ministerio de Fomento para a posta en valor de 18 castros da provincia de Pontevedra, "en 2016 traballamos na recuperación deste espazo e agora levamos preto de dous meses desde que se retomaron os traballos" cos obxectivos de "completar a escavación de dúas estruturas que xa estaban localizadas e realizar a consolidación que permita que non se perdan todos os achados". Carmela Silva sinalou que entre 2016 e 2017 "estamos a falar de máis de 500 metros escavados" e asegurou que "os traballos de conservación están a piques de rematar"». https://www.depo.gal/-/noticia-carmela-silva-visita-castro-alobre-onde-estan-apiques-de-rematar-os-traballos-de-consolidacion-previos-a-sua-musealizacion.
} 
como recheo dos diferentes espazos, diferenciando así as estruturas romanas das da Idade do Ferro. No proxecto maniféstase que está prevista unha ampliación da zona escavada cara ao norte e que por ese motivo se mantén esa zona libre de "contidos" e por iso aparece no proxecto como Zona Futuras Escavacións.

Deste modo, non hai unha confluencia entre investigación e intervención; son procesos que se desenvolveron independentemente e os proxectos non atenden á investigación para definir os criterios de intervención, senón que aplican uns criterios comúns para xacementos dos que existen distintos graos de coñecemento, algún deles en proceso de investigación, como é o caso de Alobre, ou non incorporan na actuación a totalidade das estruturas e do coñecemento actual do xacemento, como é o caso da Subidá. Ademais, non consta a participación dos arqueólogos que estudaron e escavaron os xacementos na definición dos proxectos de musealización, tampouco se avaliou a necesidade de dispoñer dun maior coñecemento dos xacementos, ou a súa suficiencia, para explicalos dentro do programa museográfico e de posta en valor.

\subsection{Fase de conservación}

O PPT establece que as actuacións de Mantemento e Conservación preventiva das estruturas e das áreas escavadas dos xacementos son actuacións que corresponde realizar á Deputación e non ao Ministerio de Fomento, polo que non se incluirían nos proxectos. No Prego non se contemplaba a necesidade de realizar actuacións de conservación en ningún dos tres xacementos sobre os que se intervén, e unicamente no castro de Alobre se consideraba necesario realizar actuacións de consolidación e restauración dos restos exhumados. Estas actuacións serían as que se levaron a cabo entre os anos 2016 e 2017 por parte da Deputación de Pontevedra.

Porén, as actuacións de adecuación vexetal do ámbito dos xacementos e do seu contorno, que si se incluíron nos proxectos, terían o carácter de actuacións de conservación, e como tales se tratarían nos proxectos en que se inclúe como estratexia: "Una intervención en la naturaleza, que recree la memoria del paisaje a través del mantenimiento, consolidación y en muchos casos recuperación de la vegetación autóctona perdida” (Memoria Xustificativa, 1.2 Estrategias proyectuales). Malia que se chega a manifestar na Memoria do proxecto que se realizou un estudo da topografía e da vexetación autóctona de cada xacemento e que se analizou a evolución histórica da súa paisaxe co 
fin de recuperar o estado natural do asentamento, non consta no proxecto ningún dato nin referencia concreta a tal estudo e investigación, datos que son básicos para comprender e xustificar as decisións tomadas. Contrariamente a esta estratexia “de conservación”, logo trátase a vexetación como un reclamo empregando especies de floracións vistosas de orixe maioritariamente exótica e utilizadas na xardinaría actual ${ }^{16}$, coas que se axardinan os castros de Alobre e da Subidá, por moito que no orzamento se agrupen estas actuacións como “Tratamiento del Paisaje”; non contribúe a manter os valores culturais e ecolóxicos da paisaxe do lugar, senón que a transforma introducindo elementos novos.

${ }^{16}$ Especies para empregar no Castro Alobre:

- Equisetum hyemale, planta acuática ornamental.

- Ophiopogom nigra, variedade hortícola xaponesa.

- Cornus sanguinea. En Galicia, só Valdeorras.

- Acorus gramineus Ogon, tipo de planta acuática hérbacea, da familia Araceae, oriúnda de Asia Oriental.

- Carex comans Bronze, orixe Nova Zelanda.

- Potentilla sufruticosa.

- Cotoneaster dammeri, orixe Asia, China.

- Agapanthus africanus azuis, Sudáfrica.

- Aucubas japonicas, bosques de vales e montañas do Xapón e China.

- $\quad$ Ajuga reptans. En Galicia aparece nas 4 provincias, pero é máis frecuente nas 2 do norte. Especies no Castro da Subidá:

- Cytissus Scoparius Ruby. Tipo de xesta de cor vermella.

- Cytissus andreanus ruby.

- Erica arborea. En Galicia atopámola no sueste.

- Erica darleyensis.

- Erica white.

- Calluna vulgaris (queiruga, carroucha).

- Daboecia cantabrica (queiroa, uz).

- Ruscus acuelatus (xibarda), en carballeiras e soutos.

- $\quad$ Ajuga reptans. En Galicia aparece nas 4 provincias, pero é máis frecuente nas 2 do norte.

- Hydrangea paniculata (tipo de hortensia).

- Cytissus burwoodi. Centro e oeste de Europa. 


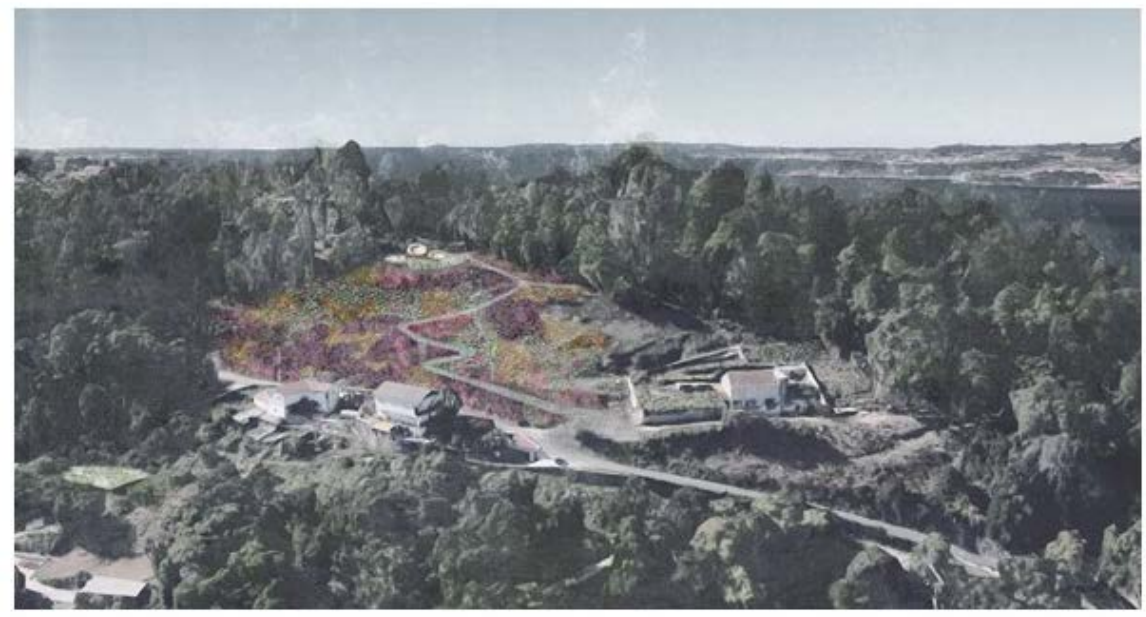

Fig. 5. Imaxe paisaxística do castro da Subidá @agi-architects

Non se realiza unha adecuación vexetal do contorno que debería avaliar as condicións de percepción do xacemento, o exceso de vexetación que o oculta, ben funcionando como barreira visual ou camuflando o xacemento. No castro da Subidá este acondicionamento é especialmente intenso, coa intención de "crear un manto de color en el paisaje que sirva como reclamo visual” (Fig. 5), sen recuperar a presenza como fito na paisaxe do xacemento.

\subsection{Fase de presentación e interpretación}

A Memoria de musealización dos xacementos non é tal, xa que non inclúe ningún contido relativo ás decisións de musealización e interpretación dos xacementos, nin individualizadamente nin do conxunto, senón que se limita a definir os diferentes modelos de elementos sinalizadores e o contido gráfico e escrito dalgún deles.

Dous elementos fundamentais dunha actuación deste tipo son a contextualización histórica e xeográfica e a definición do ámbito que musealizar, identificando o xacemento e os espazos sobre os que se vai actuar, atendendo tamén á súa compoñente territorial. Ningún destes aspectos se decide durante a elaboración do proxecto de musealización, senón que se fai a priori.

O ámbito de actuación está establecido como punto de partida dos proxectos e atende a criterios diferentes que aparentemente responden a cuestións alleas á interpretación dos xacementos, como podería ser o da dispoñibilidade dos terreos. En Toiriz actúase sobre todo 
o ámbito do xacemento, mentres que na Subidá e en Alobre se realiza a intervención unicamente sobre a área escavada. Non consta na Memoria por que se seguen eses criterios, nin se argumenta a capacidade dos ámbitos “musealizados” para explicar os xacementos. Así, non se pon en relación a musealización coa valorización e explicación dos valores culturais dos xacementos, aspecto que, como dixemos, debería ser o obxectivo principal deste tipo de actuacións.

No que respecta ao contexto histórico e xeográfico remítese á identidade da ruta Trazas de Pontevedra, na que, como xa sinalamos, a elección dos xacementos e a coherencia do conxunto non están debidamente xustificadas e a súa capacidade para ilustrar o territorio castrexo é discutible.
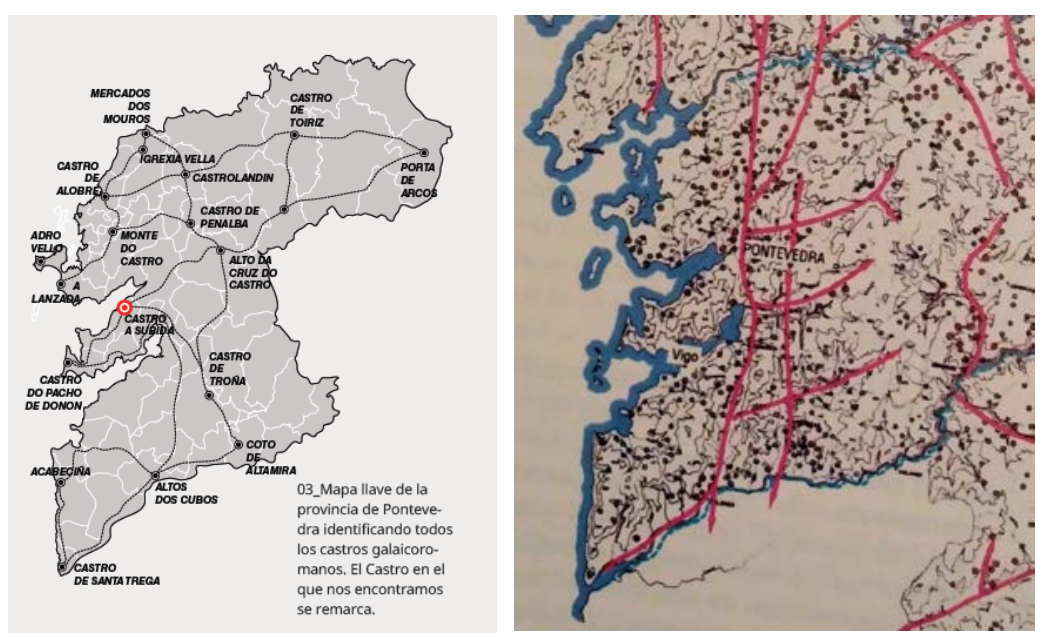

Fig. 6. Imaxe que identifica na musealización “todos” os castros galaico-romanos (Memoria de musealización do proxecto) en relación coa imaxe do mesmo territorio cos castros identificados por A. Bouhier e as rutas naturais (Nárdiz 1992).

O mapa que sitúa cada xacemento na ruta, o situado á esquerda na Fig. 6, induce unha imaxe dunha distribución homoxénea no territorio dos xacementos galaico-romanos e unha conexión ou comunicación entre eles que non se corresponde coa realidade, e dálles unha relevancia e singularidade que nada ten que ver coa realidade da distribución no territorio, como podemos ver no mapa situado á dereita, que recolle a densidade dos castros no mesmo ámbito do territorio en 1992.

Nada explica a Memoria de musealización sobre o acceso e comprensión dos xacementos, un dos principios da Carta ICOMOS para a Interpretación e Presentación de Sitios de Patrimonio Cultural, que recolle aspectos como os seguintes: Os programas de “interpretación e 
presentación deben identificar e analizar o seu público. Todos os esforzos deben realizarse para comunicar o valor do sitio patrimonial e o seu significado a todos os públicos. Todas as infraestruturas interpretativas visibles (tales como puntos de información, sendeiros e paneis de información) deben ser sensibles ao carácter, situación e relevancia cultural e natural do lugar, ademais de ser facilmente identificables”.

Non se identifican os públicos obxectivos nin se analiza como comunicar os xacementos aos distintos públicos nin a capacidade de facelos comprensibles. Tampouco se relacionan as infraestruturas interpretativas co lugar e carácter de cada xacemento, recorrendo á repetición de modelos guiada pola idea de imaxe da ruta deseñada pola Deputación Provincial máis que polas características propias de cada xacemento.

\subsection{Fase de xestión}

Non consta a existencia de ningunha estratexia nin mecanismos de xestión, control de acceso, mantemento e conservación dos xacementos. Menciónase na Memoria do proxecto varias veces a non necesidade de mantemento en relación coa vexetación (refírese ao tipo de axardinamento proxectado, ignorando que todas as superficies necesitarán no futuro dun control da vexetación espontánea) e para xustificar que non se considere necesario conectar cos servizos urbanos.

\section{AVALIACIÓN DAS ACTUACIÓNS PROXECTADAS}

As actuacións proxectadas son consideradas pola Subdirección de Conservación e Restauración de Bens Culturais ${ }^{17}$ como actuacións de valorización definidas no art. 40 da LPC/16. Non se xustifica no informe esa consideración, malia que poderían contemplarse como unha das actividades arqueolóxicas definidas no art. 95 da mesma lei e incluídas no tipo definido no apartado f): "Os labores de protección, acondicionamento, conservación, consolidación e restauración arqueolóxica, entendidos como as intervencións en xacementos arqueolóxicos encamiñadas a favorecer a súa conservación e preservación e que, en consecuencia, permitan o seu desfrute e acceso público e faciliten a súa comprensión e uso social” ${ }^{18}$. Aínda que, como se

\footnotetext{
${ }^{17}$ Informe resumido da Subdirección Xeral de Conservación e Restauración de Bens Culturais en relación co asunto, incorporado como Anexo I á Memoria xustificativa do proxecto.

${ }^{18}$ No Decreto 199/1997, do 10 de xullo, polo que se regula a actividade arqueolóxica na

Comunidade Autónoma de Galicia, a relación de actividades arqueolóxicas non se corresponde coas recollidas na LPC vixente; as actuacións proxectadas estarían comprendidas nas descritas no
} 
describiu nos apartados anteriores, nos proxectos non se actúa directamente sobre materiais arqueolóxicos ${ }^{19}$, as actuacións de acondicionamento e sinalización realízanse sobre o ámbito de protección integral do xacemento.

$\mathrm{O}$ art. 43 da LPC/16 regula o contido do proxecto de intervención que sería preceptivo elaborar para o tipo de intervención de valorización considerada no informe citado:

[...] conterá os seus datos de identificación, o estudo do ben e da súa documentación histórico-artística, a análise previa física, química ou biolóxica, segundo o caso, fichas de diagnose do seu estado de conservación, a proposta e metodoloxía de actuación, a análise crítica do valor cultural e da avaliación da proposta, as técnicas, produtos e materiais que se van empregar, a documentación gráfica da actuación e o programa de mantemento e conservación preventiva.

O proxecto non responde, nin na súa estrutura, nin no seu contido, ao requirido na LPC/16. Como se detalla a continuación, o estudo dos xacementos e a diagnose do seu estado de conservación son claramente insuficientes. Non se inclúe nin a análise crítica do seu valor cultural, nin se fai unha avaliación da proposta, nin se incorpora un programa de mantemento e conservación preventiva.

\subsection{Análise da documentación}

\section{Castro da Subidá}

Na Memoria faise unha descrición moi superficial, por non dicir nula, do xacemento: "El castro de A Subidá estuvo delimitado por dos recintos amurallados. Se situaba el primero y más exterior en la parte baja del asentamiento, y el segundo, e interior, en la cumbre” (Fig. 7a). Esta descrición é a que se inclúe no texto do panel que expón a configuración do Castro na Memoria de musealización; ao contrastala coa contida na

\footnotetext{
apartado c): “Os labores de protección, consolidación e restauración arqueolóxica, entendidos como as intervencións en depósitos arqueolóxicos encamiñadas a favorecer a súa conservación e que, en consecuencia, permitan o seu desfrute e faciliten o seu acrecentamento. Terán así mesmo esta consideración os traballos de sinalización e limpeza de depósitos arqueolóxicos”. ${ }^{19}$ Afirmación matizable, pois o feito de intervir sobre o castro e a súa área de protección, introducindo elementos que o poden modificar, suporía unha intervención directa sobre materiais arqueolóxicos, se entendemos un xacemento como un todo composto polo espazo en que interveñen as comunidades humanas e a materialidade derivada desa intervención; é dicir, como unha paisaxe cultural tal e como a describe o Convenio da Paisaxe do ano 2000 e recolle a $\mathrm{LPC} / 16$.
} 
ficha do catálogo do planeamento de Marín ${ }^{20}$, pon en evidencia o seu esquematismo.

Non se achega ningún dato/imaxe ou análise sobre a zona de localización total do castro e da súa área de influencia, e a valorización faise unicamente do espazo onde hai vivendas e deste na parte escavada (Fig. 7a e 7b). Non se contempla o coñecemento dos procesos de formación e de uso do espazo e da paisaxe circundante. O castro non pode ser entendido unicamente como un espazo poboacional, senón que é fundamental coñecer a súa relación co territorio inmediato onde se explotan os recursos económicos xa que as interaccións destes diferentes dominios e cos demais poboados teñen a súa consecuencia na configuración do espazo urbanizado (Carballo 1996).

Na interpretación do lugar, por que pararnos na época castrexa? Por que non facer unha historia diacrónica do sitio, que o máis posible é que tivese outros usos ao longo do tempo como lugar conspicuo e de gran visibilidade da contorna? Esta carencia evidénciase no descoñecemento do que pode significar a existencia de canteiras. As canteiras ou os lugares de extracción poden ser de época contemporánea, pero tamén histórica, espazos de aproveitamento de recursos óptimos en épocas diversas. Forman parte da historia do sitio e da transformación da paisaxe ao longo do tempo.

Nos planos non se sitúa o petróglifo (denominado PETROGRIFLO no panel correspondente da Memoria de musealización), de difícil visibilidade, nin tampouco na Memoria se dan datos da súa localización, motivos representados, dimensións etc., nin se definen actuacións na súa contorna.

Nos planos non se recollen elementos que poden considerarse alleos ao contexto da musealización, como os postes dos tendidos aéreos

\footnotetext{
${ }^{20} \mathrm{O}$ recinto superior ten planta oval dividida por un coial en dúas pequenas elevacións. A finais do século pasado (Ficheiro Museo de Pontevedra) conservábanse aínda parte das súas murallas, que presentaban a forma dun dobre recinto, así como o camiño estreito que desde o val daba acceso ao castro, coas escaleiras de entrada. Aínda se pode advertir a existencia dun relanzo onde se levantaban vivendas circulares.

Ten pegados dous recintos: un na súa parte oriental (...) así como un muro dunha construción de planta cadrada ou rectangular. No flanco oriental do baixo recinto meridional, a media ladeira e nun pequeno relanzo sobre a pendente, aparecen estruturas habitacionais de planta circular, un piso de sabre e un fogar. Polo oeste, aproveitando un amplo socalco natural, atópase o segundo gran recinto defendido por unha muralla exterior. Cara ao norte e ao pé do terraplén, esténdese unha ampla plataforma que podería ter estado integrada no asentamento castrexo. Podemos sinalar polo menos a existencia de cinco concheiros, tres na ladeira oriental e dous na occidental... (FICHA ARQUEOLÓXICA Y14 do Catálogo de xacementos Arqueolóxicos do PXOM de Marín. 2012. Ficha Castro e Petróglifo da Subidá GA36026010. Descrición segundo Inventario de Xacementos Arqueolóxicos da Xunta de Galicia).
} 
a carón dos que logo se instalaría o punto de información no acceso urbanizado. Ou, por exemplo, non se corresponden as picas de sinalización representadas coas recollidas no orzamento, e a súa designación nos planos non coincide coa que recolle a Memoria de musealización.
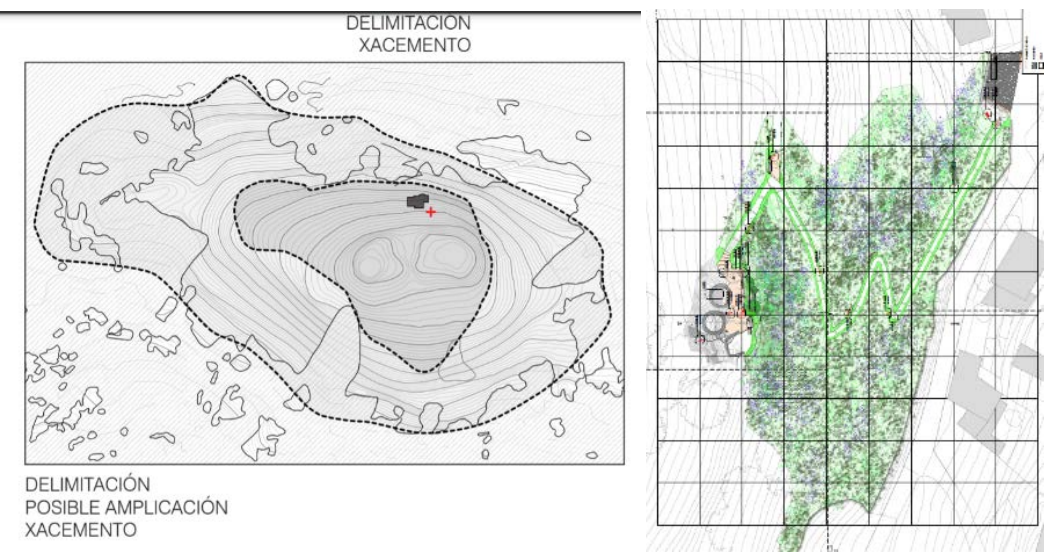

Fig. 7a.“Esquema” Castro A Subidá segundo o panel da Memoria de musealización. 7b. Ámbito de actuación do proxecto.

\section{INFORMES}

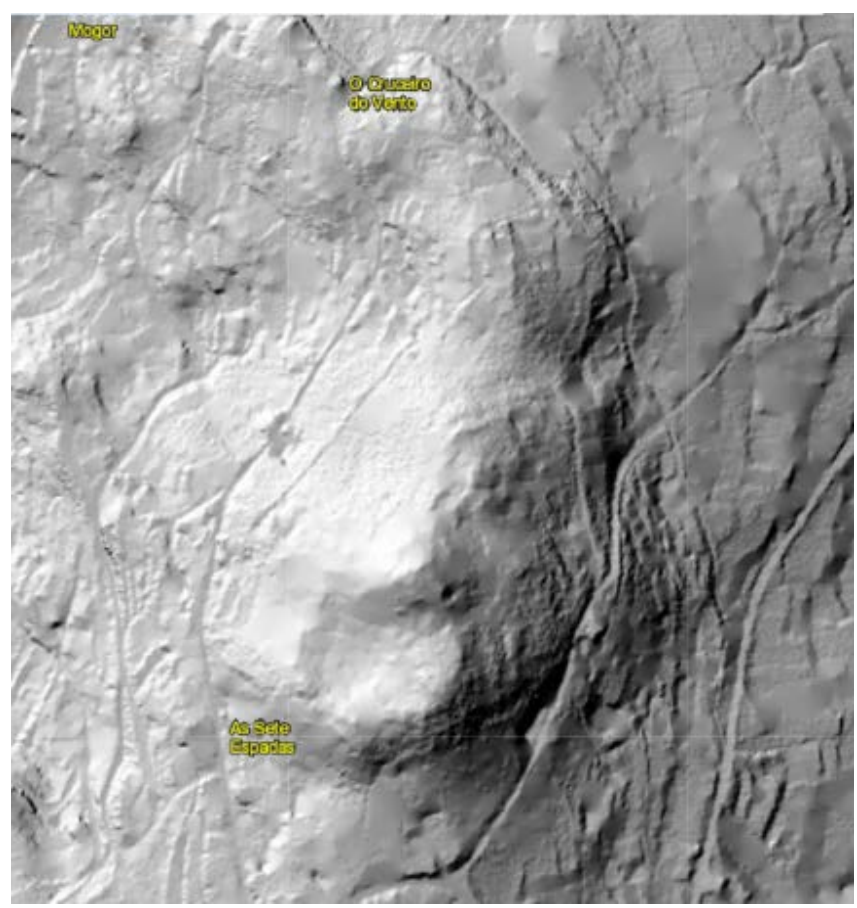

Fig. 7. c. Ámbito do castro da Subidá 


\section{Castro de Toiriz}

Contra o sinalado na Memoria do proxecto, o castro de Toiriz está incluído no catálogo de Patrimonio Cultural de Galicia, xa que está recollido no Catálogo do Plan Básico Autonómico. A documentación achegada no proxecto é moi deficitaria en canto á descrición e valores arqueolóxicos do castro, se temos en conta que, nos criterios de interpretación, musealización e posta en valor dun ben arqueolóxico, o primeiro paso é proceder ao seu estudo e documentación: "Plantear acciones de conservación, presentación o interpretación cuando se carece de estudios pormenorizados es una actuación irresponsable que puede ocasionar daños irreparables al patrimonio arqueológico” (LópezMenchero 2012).

Os contidos limítanse a unha descrición superficial do castro, aos datos perceptibles superficiais de localización, situación e conservación, que non vai máis alá do recollido pola ficha de inventario da DXPC da Xunta de Galicia. Como se sinalou, a única actuación para o coñecemento pormenorizado do castro, xunto coa súa catalogación, foi unha prospección xeofísica e xeomagnética realizada no ano 2012, e, aínda que os resultados da intervención non invasiva resultaron positivos, non son concluíntes; é dicir, para identificar os restos arqueolóxicos conservados no castro e caracterizalos, se ese é o obxectivo da musealización, cómpre levar a cabo un estudo e intervención de maior calado que permita coñecer o lugar antes de propoñer unha intervención del. Nos planos do proxecto non están recollidos os datos desa prospección, aínda que parece que serviron de referencia para deseñar e situar sobre as trazas identificadas na prospección xeofísica e xeomagnética os bancos traza e a traza fotoluminiscente. Como se aprecia nas figuras $8 \mathrm{a}$ e $8 \mathrm{~b}$, o camiño trazado non é unha envolvente perimetral das edificacións do castro que identifica a prospección senón que atravesa as situadas no cadrante nordeste. 


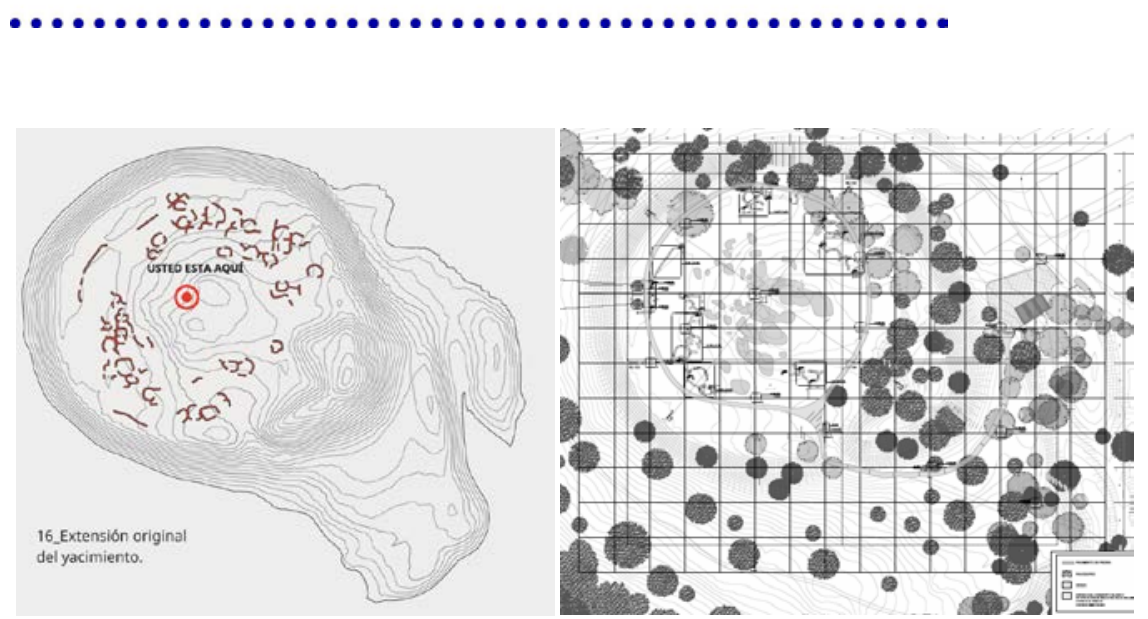

Fig. 8a. Imaxe do panel do contorno da escavación. 8b. Planta xeral do proxecto Castro de Toiriz (imaxes recollidas da Memoria de musealización Castro Toiriz).

Castro de Alobre

A intervención parte do estado do castro despois das intervencións de consolidación realizadas pola Deputación de Pontevedra logo das escavacións levadas a cabo nos anos 2016 e 2017. A Memoria do proxecto limítase a describir o xacemento, a súa localización e as escavacións realizadas, así como o estado final despois da consolidación.

Malia que a Memoria sinale que a área de actuación debe transcender o contorno inmediato do xacemento (esta referencia é confusa en todo o proxecto, referíndose case sempre ao ámbito escavado), igual que no caso do castro da Subidá, a documentación non incorpora datos/imaxes ou análises sobre a zona de localización total do castro e da súa área de influencia e a valorización faise unicamente da parte escavada (Fig. 9). Aínda que se menciona na Memoria a "Necrópolis romana, restos arquitectónicos reconocidos como pertenecientes a una factoría de salazón y un ara romana dedicada al dios Neptuno unida a restos de estructuras arquitectónicas), que confirmaron la existencia de un yacimiento castreño y, posiblemente, una villa romana litoral al pie del promontorio", estes restos non se teñen en conta na intervención de musealización. 


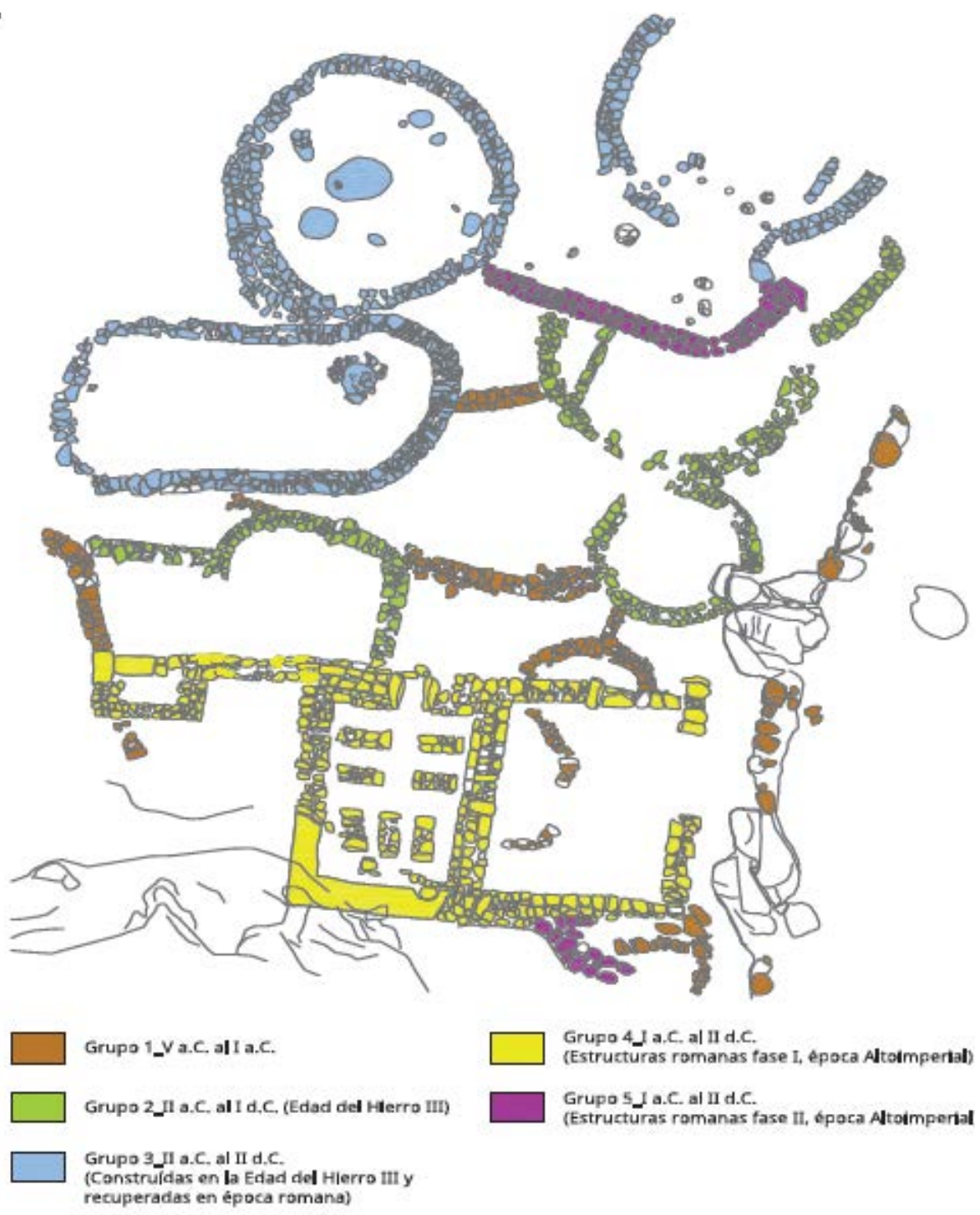

Fig. 9. Imaxe das estruturas escavadas que explicaría a superposición das sucesivas ocupacións do castro de Alobre (imaxe recollida da Memoria de musealización).

A intervención limítase a pavimentar con pezas de granito dispersas sobre o terreo arredor do camiño de subida e espazadas no propio camiño, definindo unha "greca" no límite oeste da zona escavada. Na subida paviméntase unha zona de descanso e outras dúas áreas, unha a carón da zona escavada e outra no límite da zona sobre a que se desenvolverá unha nova escavación. 


\subsection{Estudo antropolóxico}

Segundo a Carta do ICOMOS para a Interpretación e Presentación de Sitios de Patrimonio Cultural, un dos obxectivos para este tipo de proxectos sería: "Facilitar a participación e a inclusión social na interpretación do patrimonio cultural facendo posible o compromiso dos axentes implicados e as comunidades asociadas no desenvolvemento e a implementación de programas interpretativos”.

Pódese constatar que as intervencións proxectadas se deseñaron sen contar coas comunidades asociadas aos xacementos. Este feito está detrás, por exemplo, da solicitude de emisión dun informe ao CCG por parte de varias asociacións culturais.

\section{Castro da Subidá}

Achégase unha visión de xacemento como obxecto, non como un lugar integrado nun espazo social. A actuación amosa o descoñecemento do patrimonio inmaterial, tanto do contido máis simbólico como da memoria colectiva da cidadanía arredor deste xacemento e do seu contorno. Este punto é de suma importancia xa que a alteración/turistificación/musealización do castro comporta unha serie de cambios que poden supoñer a desaparición da memoria recente. Bótase en falta un proxecto participativo en colaboración coa xente que habita o lugar, xa que nas proximidades hai varios núcleos de poboación, e especialmente coa comunidade científica.

\section{Castro de Toiriz}

A actuación parte desde o seu inicio dunha falta de integración no proxecto da veciñanza máis próximo ao castro de Toiriz. É unha "musealización" imposta desde arriba, sen contar coas comunidades locais, unha maneira de abordar o proxecto que podería levar ao seu fracaso no futuro pola falta de identificación con el das comunidades locais. A veciñanza de Silleda xa expresou neste ano 2021 a súa percepción moi negativa en canto ao resultado do proxecto desenvolvido pola Deputación de Pontevedra e o Ministerio de Fomento, reflectido en varios artigos de prensa, en numerosas protestas nas redes sociais e nunha petición de change.org dirixida ao concello de Silleda e asinada por máis de 1.500 persoas. Entre os anos 2004 e 2010, a veciñanza de Silleda creara o Colectivo pola Recuperación do Castro de Toiriz, que se abría ao público, despois de moito traballo e esforzo levado a cabo polos 
veciños da vila, "limpo, digno e rehabilitado" ${ }^{21}$. O actual proxecto non ten en conta esa realidade.

\section{Castro Alobre}

Non se incorpora ningunha referencia á memoria cidadá arredor deste xacemento nin ao seu valor simbólico pola súa vinculación coa evolución histórica de Vilagarcía de Arousa e tamén pola súa relevancia na historia da arqueoloxía galega. Tampouco se consideran outros valores inmateriais como a versión da lenda do túnel de Lobeira que sitúa a saída deste baixo uns penedos no alto do castro, relacionándoo cun sitio de reunión e escape de ladróns da vila, ou co topónimo O Castriño, que se conserva xunto coa memoria do lugar como inhóspito (Ficha Castro de Alobre recollida en patrimoniogalego.net).

\subsection{Avaliación da adecuación das actuacións}

Analízase en relación cos seguintes principios: finalidade, rigorosidade histórica, interdisciplinariedade, autenticidade e mínima intervención.

\section{Finalidade}

A intervención no castro de Toiriz tal e como a describe a Memoria do proxecto ten tres obxectivos: 1) achegar unha configuración intuitiva do xacemento (obxectivo que analizaremos cos elementos de interpretación); 2) engadir valor plástico ao contorno, land-art; e 3) crear un contorno para uso lúdico. Na propia descrición do proxecto evidénciase claramente que o desfrute prima sobre a protección do xacemento e a súa conservación, aspectos que non se contemplan.

No castro da Subidá reitérase a consideración do visitante como eixe da intervención: aparcadoiro para facer máis cómodo o acceso, zonas de descanso para facer máis agradable o ascenso, plataforma para ofrecer experiencia máis cómoda ao visitante.

\footnotetext{
${ }^{21}$ https://www.elcorreogallego.es/hemeroteca/silleda-cumple-sueno-castro-toiriz-abiertopublico-AECG555566

https://www.xunta.gal/hemeroteca/-/nova/004501/inauguradas-obras-recuperacion-castrotoiriz-silleda
} 


\section{Rigorosidade histórica}

A intervención non pode atender ao principio de rigorosidade histórica, dado que a exactitude e perfección posible da información transmitida están limitadas, por unha banda, polo insuficiente coñecemento histórico dos xacementos sobre os que se intervén; por outra, por tratarse en dous dos casos de intervencións sobre fragmentos dos xacementos dos que non é posible avaliar a representatividade; e, finalmente, porque chaman a atención sobre aspectos concretos e específicos, non necesariamente exclusivos de cada xacemento. Tampouco cabe entrar máis profundamente nesa análise xa que a Memoria de musealización non recolle máis que os contidos informativos do xacemento da Subidá.

\section{Interdisciplinariedade}

O prego do concurso de ideas convocado polo Ministerio de Fomento esixía a participación no equipo dun arquitecto con coñecementos e experiencia en musealización e posta en valor de xacementos arqueolóxicos e/ou bens culturais, dun responsable de contidos con experiencia na elaboración de guións de exposicións e museos, e dun deseñador creativo para sinalización e grafismo, tamén con experiencia na aplicación en museos, exposicións ou interpretación de bens culturais.

Como xa sinalamos, a LPC/16 require que os proxectos de intervención sexan redactados por un ou unha profesional, ou por un equipo interdisciplinario, que conten con formación e cualificación suficiente en materia de investigación, conservación, restauración ou rehabilitación dos bens integrantes do patrimonio cultural en función das intervencións que se proxecten. Se a intervención se considerase unha actividade arqueolóxica, art. 95 f) da LPC/16 ou art. 2 c) do Decreto 199/1997, esta tería que estar dirixida e realizada por persoas que posúan o título superior con estudos de prehistoria e arqueoloxía, con experiencia demostrada na actividade.

Na memoria do proxecto consta o equipo redactor, director do proxecto e colaboradores, todos eles arquitectos e non consta no documento a participación doutros especialistas. 
A Carta do ICOMOS para a Interpretación e Presentación de Sitios de Patrimonio Cultural recolle como un dos seus principios o seguinte:

Respetar la autenticidad del patrimonio cultural comunicando la importancia histórica y su valor cultural y protegiéndolo del impacto adverso de infraestructuras interpretativas intrusivas, la presión de los visitantes e interpretaciones inexactas o inapropiadas que comprende: La interpretación y presentación deben contribuir a la conservación de la autenticidad de un sitio patrimonial dando a conocer su importancia sin un impacto adverso en sus valores culturales o alterando irreversiblemente su estructura e Todas las infraestructuras interpretativas visibles (tales como puntos de información, senderos y paneles de información) deben ser sensibles al carácter, situación y relevancia cultural y natural del lugar, además de ser fácilmente identificables.

Neste sentido, cómpre avaliar o rigor da interpretación dos sitios, o grao de intrusión no xacemento das infraestruturas interpretativas e a súa adecuación ao carácter cultural e natural do lugar así como o grao de alteración da súa estrutura. O concepto de mínima intervención non se pode referir unicamente á afección aos restos arqueolóxicos soterrados, senón que cómpre avaliar a desnaturalización do ámbito do xacemento urbanizando e a alteración do espazo con criterios de deseño e tratamento propios de espazos de carácter lúdico e de recreo social, mais non dun xacemento arqueolóxico.

Unha intervención de restauración nestes xacementos non debería deixar de acometer en todo o seu ámbito a protección fronte aos labores forestais ou agrícolas e o crecemento vexetal sobre o xacemento, que pon en risco a súa conservación; tamén nos que non se "musealizan” por non conter restos escavados, como gran parte da superficie dos castros de Alobre ou da Subidá.

\section{ELEMENTOS DE INTERPRETACIÓN}

O concurso requiría definir unha proposta xenérica de intervención na ruta coa definición tamén xenérica de elementos de musealización, sinalización e mobiliario para os xacementos: accesibilidade, mobiliario e equipamentos, sinalización, soportes para pezas, información textual e gráfica, condicións ambientais e iluminación. É dicir, a idea de partida do proxecto é a de uniformización dos xacementos a través da aplicación de 
criterios comúns de intervención, incluso dos elementos de musealización.

\subsection{Cartelaría e sinalización}

A definición dos elementos de sinalización e cartelaría realízase nas Memorias de carpintaría de cada unha das intervencións nuns esquemas que definen as dimensións xerais e os materiais, aceiro corten e aceiro inoxidable e no orzamento do proxecto onde se concreta a definición de materiais e tratamentos.

\section{Castro de Alobre}

Dos elementos definidos, practicamente a metade son picas fotoluminiscentes e só cinco, ademais do punto de información da ruta e as denominadas picas cronoloxía, corresponden a contidos sobre $o$ xacemento. Destas unicamente está indicado o tema de dous deles, isto é, achegamento xeográfico e achegamento sociocultural (este sería do tipo pica con son) e dun terceiro denominado concheiro. Non constan na Memoria de musealización os contidos e sinálase que os gráficos son orientativos.

Ás picas fotoluminiscentes hai que engadir os tocos de árbores con resina fotoluminiscente que acompañan o percorrido ata a zona escavada.

\section{Castro de Toiriz}

A sinalización é semellante á descrita de Alobre. Novamente, máis da metade das picas son do tipo luz, fotoluminiscentes, e inclúense dúas sonoras e dúas que relacionan o castro de Toiriz cos de Cascaxide e Torrón, ademais da que incorpora os resultados da prospección realizada e unha relativa ao achegamento xeográfico. Engádese unha pica cronoloxía e o punto de información da ruta cunha barreira no inicio do camiño pavimentado no aparcadoiro. Tampouco constan na Memoria de musealización os contidos e algún dos descritores destes non se corresponde con este castro.

\section{Castro da Subidá}

Neste xacemento a documentación é confusa. Instálase un número menor de picas luz e un número de cinco picas informativas (orzamento 
e planos), malia que na Memoria de musealización se definen seis, e nos planos aparece só unha pica mentres que no orzamento constan dúas e na Memoria de musealización non se define ningunha. A esta engádese o consabido punto de información da ruta e a pica de cronoloxía.

Este é o único dos xacementos no que se inclúe o contido informativo da cartelaría. En concreto, recóllese información sobre a situación xeográfica, a topografía do castro, a cultura material, a arquitectura das edificacións, ou outras estruturas singulares, así como aspectos relacionados cos criterios técnicos de intervención arqueolóxica. No achegamento xeográfico descríbese a situación topográfica do castro e a creación de socalcos para asentar as edificacións incorporando un perfil cun esquema dunha destes socalcos onde se sitúa o “xacemento”, confundindo este coa área escavada. No achegamento sociocultural ao sitio relaciónase con outros xacementos, a partir dunha comparativa da cultura material recuperada durante as escavacións, facendo fincapé na metalurxia. Defínense no contorno da escavación as intervencións realizadas neste xacemento e os criterios técnicos das actuacións de consolidación levadas a cabo. $\mathrm{Na}$ configuración do castro descríbese de maneira esquemática este e as edificacións que o integran, e emprégase un esquema ideal dunha edificación castrexa. Finalmente, tamén se recolle información sobre o concheiro e o petróglifo (denominado na Memoria de musealización PETROGRIFLO), mais recolle un texto de carácter xeral sobre os petróglifos e non se describe o localizado no castro.

Nesta interpretación que incluír na cartelaría, non se fai fincapé nos valores do xacemento polos cales foi seleccionado para a súa musealización, a selección de contidos mestura información xeral con información técnica moi específica, non se aprecia en xeral que se potencie o substancial e algún dos gráficos é confuso en relación aos contidos.

\subsection{Elementos (des)contextualizadores, pseudorreconstrucións}

No castro de Toiriz inclúese unha serie de elementos de nova factura cunha teórica tripla funcionalidade: a estética, sendo deseñados e conceptualizados como obras de land-art; a de uso, como bancos; e a interpretativa, porque reproducirían trazas detectadas na prospección xeofísica e xeomagnética das construcións do castro. Esas trazas achegarían ao visitante unha configuración intuitiva do "poboado existente baixo rasante”. Estes bancos realízanse con chapa de aceiro corten sobre patas formadas por platinas do mesmo tipo de chapa sobre 
a cimentación. Outra traza que non ten uso de banco está formada por un tubo de aceiro con pintura fotoluminiscente sobre patas de aceiro corten.

A función interpretativa destes elementos non está clara, xa que son reproducións formais de fragmentos de trazas dispersas no xacemento que non permiten ao visitante reconstruír a densidade das edificacións, nin o seu carácter masivo e non se perciben como un conxunto. A isto engádese que a funcionalidade e o aspecto plástico, que contrasta co lugar natural pola forma e polos materiais, e a fotoluminiscencia dificultan e ata impedirían relacionar estes elementos coa estrutura do xacemento. Por outra parte, que sentido teñen como elementos de nova estética para explicar mediante a musealización in situ os valores culturais dun castro co obxectivo de que o visitante perciba a cultura galaico-romana?

A lingua empregada nos carteis é a castelá, relegando a lingua propia de Galicia a unha posición secundaria na parte posterior, ao mesmo nivel ca o inglés, non respectando nin tan sequera a cooficialidade que recoñece o Estatuto de autonomía de Galicia. Esta escolla é aínda máis cuestionable cando entre as finalidades dos contidos que se transmitan está a de conectar a cidadanía co seu pasado e explicarlle a transformación histórica do territorio, ademais de que no proxecto se requiría facer especial referencia á utilidade para a poboación en idade escolar, un dos obxectivos prioritarios dende o punto de vista da vocación didáctica e de divulgación perseguidos (6.2 Desarrollo de Contenidos PPT).

\section{IMPACTO SOBRE O REXISTRO ARQUEOLÓXICO DAS ACTUACIÓNS}

Nas actuacións pavimentáronse novos accesos e percorridos, ata os ámbitos escavados na Subidá e Alobre, e un percorrido perimetral en Toiriz; ademais realizáronse aparcadoiros no acceso a cada un dos xacementos e zonas contiguas ás escavacións. Estas actuacións, ademais da producida pola colocación das diferentes "picas” dos bancos traza etc., levan consigo movementos de terra para construír os firmes e cimentacións, e todas elas desenvólvense no ámbito dos xacementos arqueolóxicos catalogados. No proxecto estímase a xestión de $200 \mathrm{~m}^{3}$ de terras e restos pétreos da escavación no conxunto dos tres xacementos. Preveuse a realización dunha actuación arqueolóxica para "establecer las medidas oportunas que permitan la conservación y/o documentación, de ser el caso, de las evidencias o elementos de interés arqueológico que 
aparezcan en el transcurso de las obras”; é dicir, na terminoloxía da LPC, dun control arqueolóxico previsto "para obras que afectan ou poden afectar un espazo de posible interese arqueolóxico”.

\section{INFORMES CCG}

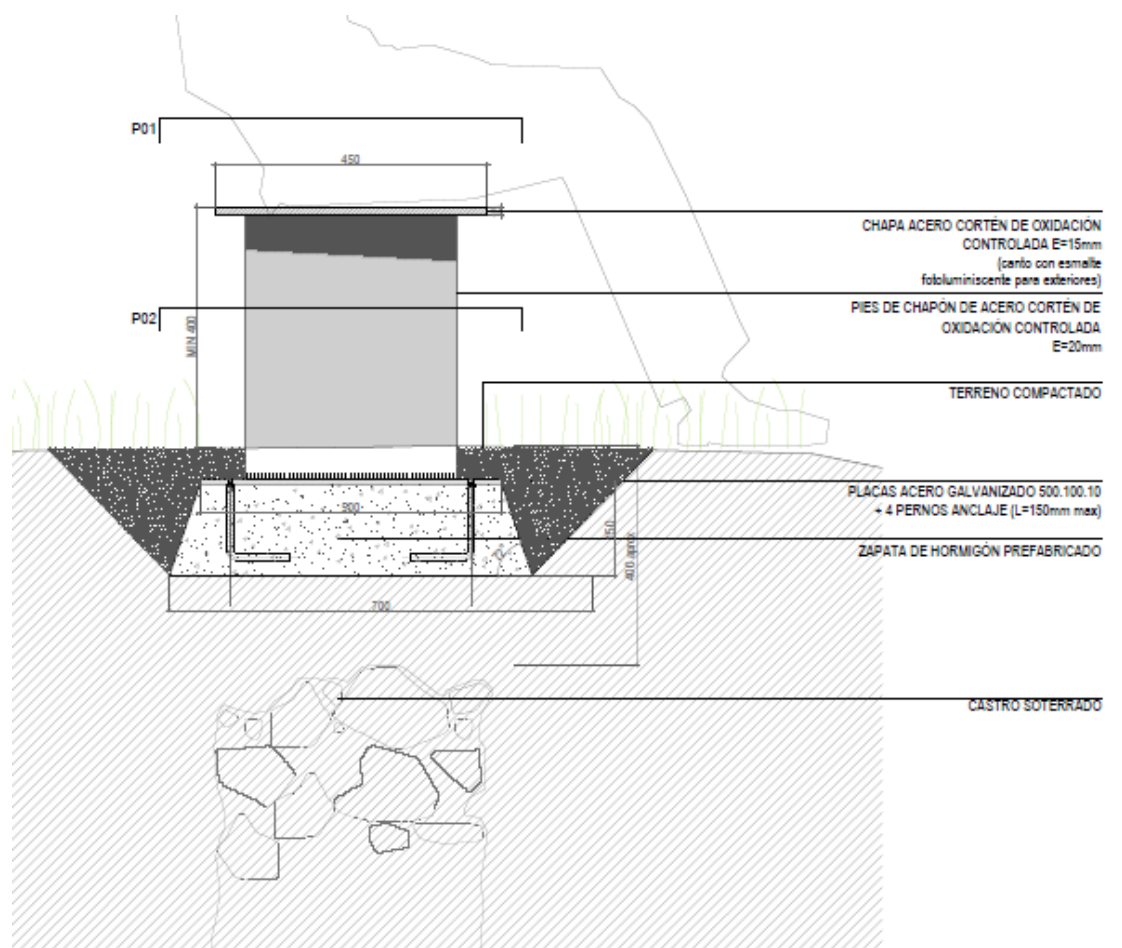

Fig. 10. Detalle do proxecto do apoio dos bancos traza sobre estruturas soterradas. 


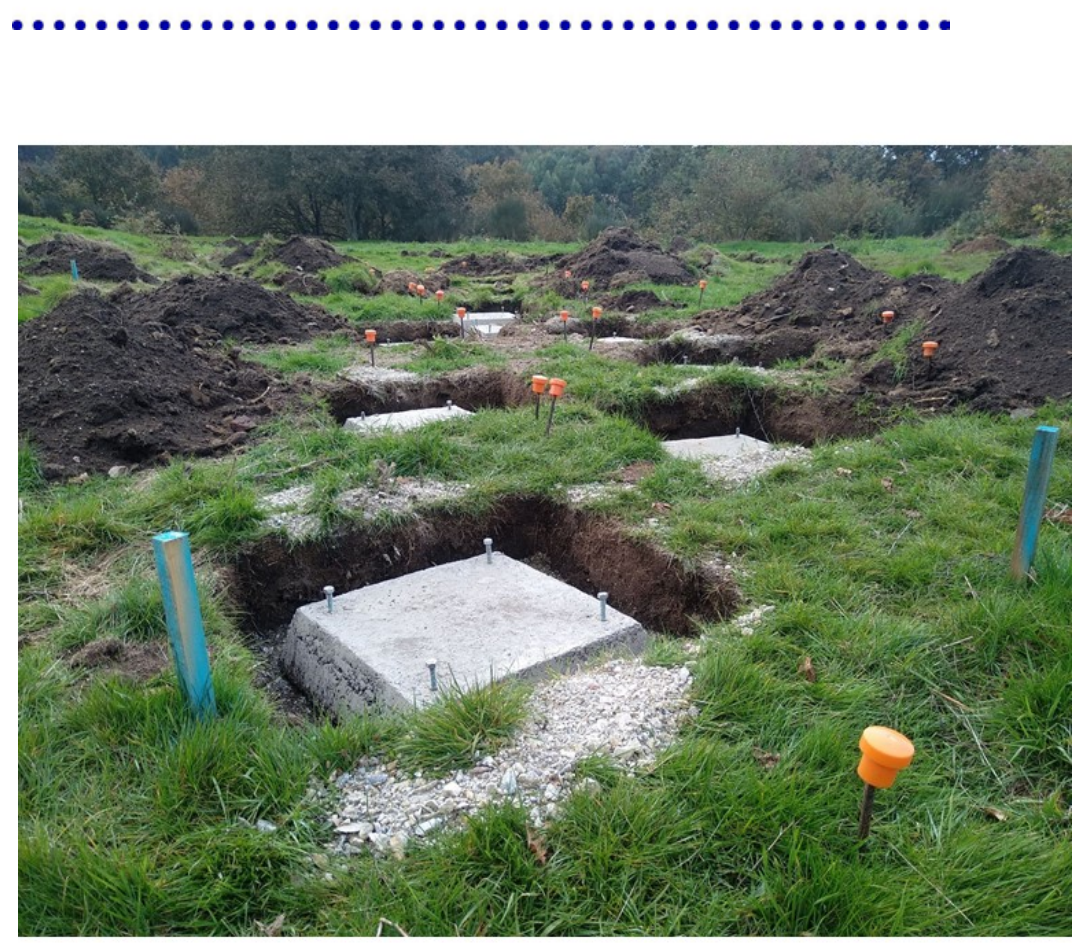

Fig. 11. Castro de Toiriz. Cimentación de bancos en execución @Faro de Vigo ${ }^{22}$

O interese dos ámbitos afectados por eses movementos de terras está constatado na medida en que todos eles forman parte das áreas identificadas e delimitadas dos castros catalogados. No caso de Toiriz, a prospección realizada localizou os restos soterrados e é sobre eles onde se proxectou colocar as pezas que reproducirían parte das trazas desas edificacións, colocando os bloques de cimentación directamente sobre eses restos (Fig. 10 e 11). Estas intervencións puxeron en risco a conservación do xacemento e, malia que se documenten ou conserven as evidencias ou elementos de interese arqueolóxico que apareceran, estas actividades realízanse fóra do contexto dunha escavación arqueolóxica coa finalidade de investigación que os contextualice e relacione, polo que se deberían limitar ás imprescindibles.

\footnotetext{
${ }^{22}$ https://galego.farodevigo.es/fotos/deza-tabeiros/2020/11/17/obras-toiriz-castro-
} 23254565.html\#foto=1 


\section{CONCLUSIÓNS}

Podemos sintetizar a análise realizada neste informe nas seguintes consideracións:

A ruta dos xacementos galaico-romanos da provincia de Pontevedra está definida como un RECURSO turístico, facendo especial énfase na accesibilidade e nunha valorización centrada na atracción e nunha información xeral, non específica, e non tratada cientificamente. Esas actuacións priman sobre os ambiciosos obxectivos científicos aos que teoricamente tamén pretendía atender: a explicación da articulación territorial e da dinámica socioeconómica da “provincia” e de Galicia na Antigüidade.

Deseñouse a ruta sen unha reflexión previa e debidamente razoada sobre a conveniencia de abrir ao público eses xacementos nin sobre a compatibilidade das actuacións coa súa protección e conservación. Simplifícase cada un deles a un "carácter único” nunha escolla que reduce o seu valor histórico e cultural. Polo menos, esa posible reflexión non está contemplada no material proporcionado para realizar este informe.

As actuacións que se proxectan sobre os xacementos, malia que se denominen de musealización, non contan coa necesaria investigación aplicada aos proxectos que contribúa a establecer os criterios de intervención e ten como obxectivo dos proxectos integrar paisaxismo, renovación e musealización, dotando de "calidade escénica e amabilidade a visita aos castros”, o que pon o foco no tratamento dos castros como un recurso que hai que facer atractivo (mais sen contar coa opinión das comunidades ao respecto disto).

O encaixe das actuacións no programa de Rehabilitación Arquitectónica do Ministerio de Fomento, que ten unha finalidade ben distinta ao uso que se lle está dando neste proxecto, foi o que requiriu probablemente esa separación entre actuacións arqueolóxicas (escavación, consolidación e restauración) e a valorización. Non hai confluencia entre investigación e intervención, actividades que se desenvolven como procesos independentes. O coñecemento científico non se aplica para definir os criterios de intervención e tampouco se avalía a súa suficiencia para explicar os xacementos, mentres que se aplican criterios comúns para xacementos de moi diverso grao de coñecemento. 
Non se poden considerar actuacións de conservación unicamente aquelas que afectan directamente a materiais arqueolóxicos obviando que as actuacións de adecuación vexetal dos castros tamén teñen ese carácter. Estas actuacións deberíanse fundamentar na análise da evolución histórica da paisaxe e avaliar as condicións de percepción dos castros, actuando sobre a vexetación que os camufla ou oculta. Fronte a isto óptase por un axardinamento, tratando a vexetación como un reclamo e introducindo especies que nada teñen que ver coa paisaxe galega.

Calquera actuación de musealización deste tipo debe partir dunha contextualización histórica e xeográfica, que no caso da identidade da ruta Trazas de Pontevedra é confusa, e da identificación do xacemento e dos espazos sobre os que se vai actuar atendendo á súa relación co territorio. As decisións tomadas ao respecto da musealización neste caso son previas, non se adaptaron nos proxectos á realidade dos sitios en que se intervén e reduciron os xacementos a fragmentos en certa medida descontextualizados.

Non hai na actuación unha reflexión sobre a interpretación e presentación dos xacementos que atenda aos públicos potenciais, nin ao público local, a comunidade patrimonial, nin ao público escolar, e tampouco sobre as particularidades de cada castro e do seu contexto. Non hai unha estratexia de xestión dos espazos musealizados, nin mecanismos de control de accesos, de conservación...

Non se parte da comprensión dos castros dende a súa integridade como espazo poboacional relacionado co territorio inmediato e ignóranse os procesos de formación e uso do espazo e paisaxe circundante, limitando no caso da Subidá e Alobre a valorización aos ámbitos parciais escavados.

No desenvolvemento das actuacións de interpretación non se contou coas comunidades asociadas aos xacementos, malia a existencia de colectivos organizados para a recuperación deste patrimonio, como o do castro de Toiriz. Tampouco se tiveron en conta a memoria cidadá arredor dos xacementos nin os contidos simbólicos ligados aos castros.

Sen entrar no debate acerca da consideración legal dos proxectos como intervención arqueolóxica e os requirimentos que diso se derivan, é indiscutible que as actuacións de intervención sobre xacementos arqueolóxicos como as realizadas deben dispor dun equipo interdisciplinario no que se debe contar co coñecemento material e inmaterial e dos valores culturais dos castros, do territorio e da súa relación dende unha perspectiva xeral e específica de cada un dos 
xacementos, e que ese coñecemento debería servir de base para establecer os criterios de intervención e presentación.

Como sinala o artigo 144.4 da LPC/16, a Xunta de Galicia e as entidades habilitadas para a autorización de intervencións no patrimonio cultural garantirán a asistencia e participación de técnicos coa competencia e coñecementos necesarios, especialmente no ámbito da historia, a arte, a conservación e restauración de bens culturais, a arquitectura, a arqueoloxía ou en calquera outra disciplina científica aplicable á natureza do ben. Atendendo á natureza dos castros de Toiriz, Alobre e A Subidá como xacementos arqueolóxicos, nas intervencións realizadas considérase necesaria a asistencia e participación de técnicos con competencia no ámbito da arqueoloxía, no coñecemento da cultura castrexa e dos xacementos nos que se intervén especificamente.

As accións de presentación e interpretación desenvólvense sen contar con estudos pormenorizados que teñan a amplitude, profundidade e rigor necesarios. No seu desenvolvemento primouse o desfrute sobre a protección, dando prioridade como criterio á comodidade do visitante e ao deseño efectista antes que á retransmisión dos valores culturais dos castros obxecto da ruta, o cal resulta paradoxal pois é este un dos obxectivos principais do proxecto.

Nas actuacións primouse a desnaturalización dos xacementos con criterios de deseño e tratamento propios de espazos doutro carácter, esquecendo a necesidade de actuacións de recuperación da paisaxe, especialmente das que permitirían recuperar a visibilidade e percepción dos xacementos, e de actuacións dirixidas á protección fronte aos usos forestais e ao crecemento vexetal sobre os xacementos.

No deseño dos elementos de interpretación primaron dous criterios: o de uniformización e o dunha certa espectacularización, tratando os castros como se fosen iguais e como tractores turísticos máis que como equipamentos culturais, deixando fóra dos proxectos os contidos, como e que se musealiza definido a priori ou o feito de como se explican os xacementos, que foi definido a posteriori na execución das obras.

Non se outorgou preferencia á protección e conservación. Así, actuacións como a de instalar elementos sobre estruturas coñecidas e documentadas puxo en risco a súa conservación e o seu estudo e investigación. 
Resulta inaceptable que se releguen os contidos en lingua galega á parte posterior dos paneis ao carón dos textos en lingua inglesa, que, ademais de mostrar o desprezo cara ao galego dende o ámbito patrimonial, ignorando o recoñecemento da lingua como patrimonio cultural inmaterial, menospreza a poboación local como comunidades patrimoniais dos xacementos e primeiros usuarios e destinatarios dos castros musealizados.

O artigo 98.2 da LPC/16 establece a obriga de velar por que as obras e actuacións necesarias para a apertura dun xacemento á visita pública non atenten contra o carácter arqueolóxico, contra o seu valor cultural e científico, contra a súa relación co contorno e co seu contexto territorial e contra a valoración cultural da paisaxe. A análise realizada evidencia que nas intervencións realizadas non se atendeu a eses criterios.

As actuacións de valorización do patrimonio con finalidade turística, realizadas para aumentar a capacidade de atracción dos sitios, non se poden limitar ás actuacións de interpretación e sinalización, esquecendo que calquera actuación deste tipo debe partir do seu estudo e documentación, incluír as actuacións de conservación necesarias para preservar o ben, no presente e no futuro, o que inclúe as actuacións de mantemento dos bens e dos elementos e infraestruturas de interpretación. (Blanco-Rotea, e.p.)

Cómpre reflexionar sobre os criterios de intervención e musealización deste tipo de xacementos, avaliando as condicións para a súa viabilidade; definindo protocolos de actuación debidamente secuenciados; desenvolvendo os contidos dos proxectos de intervención e musealización e as competencias e formación dos equipos que os desenvolvan; establecendo a obrigatoriedade dun plan de xestión que asegure a sustentabilidade do ben patrimonial, o mantemento das infraestruturas e a actualización dos contidos científicos....

Igualmente, cómpre avaliar a natureza museística deste tipo de espazos ou conxuntos e tratalos como tales, o que pode requirir a súa vinculación a algunha das institucións museísticas existentes que permita que poidan contribuír á promoción e ao desenvolvemento cultural da comunidade en xeral, e manter os fins de estudo, educación, desfrute e promoción científica e cultural que son propios destas institucións. 


\section{BIBLIOGRAFÍA}

Carballo Arceo, L. X. (1996): “Os castros galegos: espacio e arquitectura”, Gallaecia, 14-15, 309-357.

Blanco-Rotea, R. (coord./ed.) (e.p.). Foro Patrimonio e Sociedade. Guía práctica para a análise dun sector clave na gobernanza do futuro, Santiago de Compostela, Consello da Cultura Galega.

López-Menchero Bendicho, V. M. (2012): Manual para la puesta en valor del patrimonio arqueológico al aire libre, Gijón, Editorial Trea.

Villalobos-Gómez, A. (2015): Arqueología, proyecto y paisaje: musealización in situ de los dólmenes de Antequera. Tese de doutoramento. Sevilla, Universidad de Sevilla. Departamento de Construcciones Arquitectónicas I (ETSA) (consulta en https://idus.us.es/handle/11441/39148).

\section{NORMATIVA E RECURSOS WEB}

Carta ICOMOS para Interpretación y Presentación de Sitios de Patrimonio Cultural, https://www.icomos.org/images/DOCUMENTS/Charters/interpre tation_sp.pdf

Carta internacional para la gestión del patrimonio arqueológico (1990). https://www.icomos.org/images/DOCUMENTS/Charters/arch_sp. pdf

Compendio de criterios y sistemas actualizados para el tratamiento y puesta en valor del patrimonio arqueológico en entornos naturales. https://idus.us.es/bitstream/handle/11441/62759/bgrl.pdf;jsession

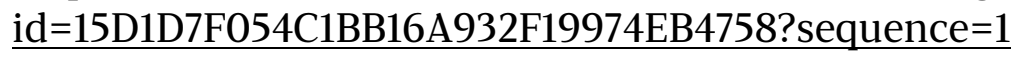

Nuevas estrategias para la puesta en valor del patrimonio megalítico. La estación dolmenica de Haizko, Karrantza (Bizkaia). https://www.bizkaia.eus/fitxategiak/04/ondarea/Kobie/PDF/2/K obie_31_web_12.pdf?hash=012a01fe6bcd67c0f6dc7d3fe239efd3 